\title{
The nitrogen budget of laboratory-simulated western US wildfires during the FIREX 2016 Fire Lab study
}

\author{
James M. Roberts ${ }^{1}$, Chelsea E. Stockwell ${ }^{1,2}$, Robert J. Yokelson ${ }^{3}$, Joost de Gouw ${ }^{1,2,5}$, Yong Liu ${ }^{4}$, Vanessa Selimovic ${ }^{3}$, \\ Abigail R. Koss ${ }^{1,2,5, a}$, Kanako Sekimoto ${ }^{1,2,6}$, Matthew M. Coggon ${ }^{1,2}$, Bin Yuan ${ }^{1,2, b}$, Kyle J. Zarzana ${ }^{1,2, c}$, \\ Steven S. Brown ${ }^{1}$, Cristina Santin ${ }^{7}$, Stefan H. Doerr ${ }^{7}$, and Carsten Warneke ${ }^{1,2}$ \\ ${ }^{1}$ NOAA Earth System Research Laboratories (ESRL), Chemical Sciences Laboratory, Boulder, CO, USA \\ ${ }^{2}$ Cooperative Institute for Research in Environmental Sciences, University of Colorado Boulder, Boulder, CO, USA \\ ${ }^{3}$ Department of Chemistry and Biochemistry, University of Montana, Missoula, MT, USA \\ ${ }^{4}$ Department of Chemistry, University of Colorado, Denver, Denver, Colorado, USA \\ ${ }^{5}$ Department of Chemistry, University of Colorado Boulder, Boulder, CO, USA \\ ${ }^{6}$ Graduate School of Nanobioscience, Yokohama City University, Yokohama, Japan \\ ${ }^{7}$ Departments of Geography and Biosciences, Swansea University, Swansea, UK \\ anow at: Tofwerk, USA, Boulder, CO, USA \\ ${ }^{b}$ now at: Institute for Environmental and Climate Research, Jinan University, Guangzhou, China \\ ${ }^{c}$ now at: Department of Chemistry, University of Colorado Boulder, Boulder, CO, USA
}

Correspondence: James M. Roberts (james.m.roberts@noaa.gov)

Received: 27 January 2020 - Discussion started: 24 February 2020

Revised: 3 June 2020 - Accepted: 22 June 2020 - Published: 24 July 2020

\begin{abstract}
Reactive nitrogen $\left(\mathrm{N}_{\mathrm{r}}\right.$, defined as all nitrogencontaining compounds except for $\mathrm{N}_{2}$ and $\mathrm{N}_{2} \mathrm{O}$ ) is one of the most important classes of compounds emitted from wildfire, as $\mathrm{N}_{\mathrm{r}}$ impacts both atmospheric oxidation processes and particle formation chemistry. In addition, several $\mathrm{N}_{\mathrm{r}}$ compounds can contribute to health impacts from wildfires. Understanding the impacts of wildfire on the atmosphere requires a thorough description of $\mathrm{N}_{\mathrm{r}}$ emissions. Total reactive nitrogen was measured by catalytic conversion to $\mathrm{NO}$ and detection by $\mathrm{NO}-\mathrm{O}_{3}$ chemiluminescence together with individual $\mathrm{N}_{\mathrm{r}}$ species during a series of laboratory fires of fuels characteristic of western US wildfires, conducted as part of the FIREX Fire Lab 2016 study. Data from 75 stack fires were analyzed to examine the systematics of nitrogen emissions. The measured $\mathrm{N}_{\mathrm{r}} /$ total-carbon ratios averaged $0.37 \%$ for fuels characteristic of western North America, and these gas-phase emissions were compared with fuel and residue $\mathrm{N} / \mathrm{C}$ ratios and mass to estimate that a mean $( \pm \mathrm{SD})$ of 0.68 $( \pm 0.14)$ of fuel nitrogen was emitted as $\mathrm{N}_{2}$ and $\mathrm{N}_{2} \mathrm{O}$. The $\mathrm{N}_{\mathrm{r}}$ detected as speciated individual compounds included the following: nitric oxide $(\mathrm{NO})$, nitrogen dioxide $\left(\mathrm{NO}_{2}\right)$, nitrous acid (HONO), isocyanic acid (HNCO), hydrogen cyanide
\end{abstract}

( $\mathrm{HCN})$, ammonia $\left(\mathrm{NH}_{3}\right)$, and 44 nitrogen-containing volatile organic compounds (NVOCs). The sum of these measured individual $\mathrm{N}_{\mathrm{r}}$ compounds averaged $84.8( \pm 9.8) \%$ relative to the total $\mathrm{N}_{\mathrm{r}}$, and much of the $15.2 \%$ "unaccounted" $\mathrm{N}_{\mathrm{r}}$ is expected to be particle-bound species, not included in this analysis.

A number of key species, e.g., $\mathrm{HNCO}, \mathrm{HCN}$, and HONO, were confirmed not to correlate with only flaming or with only smoldering combustion when using modified combustion efficiency, $\mathrm{MCE}=\mathrm{CO}_{2} /\left(\mathrm{CO}+\mathrm{CO}_{2}\right)$, as a rough indicator. However, the systematic variations in the abundance of these species relative to other nitrogen-containing species were successfully modeled using positive matrix factorization (PMF). Three distinct factors were found for the emissions from combined coniferous fuels: a combustion factor (Comb-N) $\left(800-1200^{\circ} \mathrm{C}\right)$ with emissions of the inorganic compounds $\mathrm{NO}, \mathrm{NO}_{2}$, and $\mathrm{HONO}$, and a minor contribution from organic nitro compounds $\left(\mathrm{R}-\mathrm{NO}_{2}\right)$; a high-temperature pyrolysis factor (HT-N) $\left(500-800^{\circ} \mathrm{C}\right)$ with emissions of $\mathrm{HNCO}, \mathrm{HCN}$, and nitriles; and a low-temperature pyrolysis factor (LT-N) $\left(<500^{\circ} \mathrm{C}\right)$ with mostly ammonia and NVOCs. The temperature ranges specified are based on known com- 
bustion and pyrolysis chemistry considerations. The mix of emissions in the PMF factors from chaparral fuels (manzanita and chamise) had a slightly different composition: the Comb-N factor was also mostly NO, with small amounts of $\mathrm{HNCO}, \mathrm{HONO}$, and $\mathrm{NH}_{3}$; the HT-N factor was dominated by $\mathrm{NO}_{2}$ and had HONO, HCN, and HNCO; and the LT-N factor was mostly $\mathrm{NH}_{3}$ with a slight amount of $\mathrm{NO}$ contributing. In both cases, the Comb-N factor correlated best with $\mathrm{CO}_{2}$ emission, while the HT-N factors from coniferous fuels correlated closely with the high-temperature VOC factors recently reported by Sekimoto et al. (2018), and the LT-N had some correspondence to the LT-VOC factors. As a consequence, $\mathrm{CO}_{2}$ is recommended as a marker for combustion $\mathrm{N}_{\mathrm{r}}$ emissions, $\mathrm{HCN}$ is recommended as a marker for HT-N emissions, and the family $\mathrm{NH}_{3}$ / particle ammonium is recommended as a marker for LT-N emissions.

\section{Introduction}

Wildfires have severe impacts on the chemistry of the atmosphere from local to global scales (Crutzen and Andreae, 1990). A warmer, drier climate in western North America, coupled with policies that have allowed buildup of fuels in forest ecosystems has led to increases in frequency and severity of wildfires in this region (Abatzoglou and Williams, 2016; Westerling et al., 2006). The new strategy for management of wildfire in the US is to allow fire where possible and to fight fire where needed (D. C. Lee et al., 2014). The science behind making these decisions and understanding their consequences involves, in part, a better understanding of the emissions from wildfires. The NOAA FIREX (Fire Influence on Regional and Global Environments Experiment) Fire Lab experiment was conducted in the fall of 2016, at the US Forest Service Fire Sciences Laboratory in Missoula, Montana, to acquire detailed measurements of particle and gas-phase emissions from fires involving fuels characteristic of the western US (NOAA, 2020a). Several aspects of these measurements dealing with VOC species and individual reactive nitrogen species $\left(\mathrm{N}_{\mathrm{r}}\right.$, defined as all nitrogen compounds except for $\mathrm{N}_{2}$ and $\mathrm{N}_{2} \mathrm{O}$ ) have already been published (Koss et al., 2018; Manfred et al., 2018; Sekimoto et al., 2018; Selimovic et al., 2018; Zarzana et al., 2018), including emissions factors for many of the $\mathrm{N}_{\mathrm{r}}$ species (Koss et al., 2018).

The $\mathrm{N}_{\mathrm{r}}$ compounds emitted by natural-convection biomass burning (BB) arise solely from the $\mathrm{N}$ in the fuels, since the combustion temperatures are not high enough $\left(<1200^{\circ} \mathrm{C}\right)$ to produce oxides of nitrogen $\left(\mathrm{NO}_{x}\right.$ ) from $\mathrm{N}_{2}$ and $\mathrm{O}_{2}$ (the so-called Zeldovich or thermal nitrogen cycle) (Lobert and Warnatz, 1993; Taylor et al., 2004; Wotton et al., 2012). The fuel nitrogen cycles that pertain to BB flaming combustion are shown schematically in Fig. 1 (Glarborg et al., 2018; Lobert and Warnatz, 1993; Lucassen et al., 2012; Manion et al., 2015). Note that the equations shown in Fig. 1 are meant to indicate the general flow of the chemistry and do not always convey the mechanistic subtleties of the reactions, which are fully covered in specialized references (Glarborg et al., 2018; Manion et al., 2015). $\mathrm{N}_{\mathrm{r}}$ compounds are emitted as small molecules, hydrogen cyanide ( $\mathrm{HCN})$, isocyanic acid $(\mathrm{HNCO})$, and ammonia $\left(\mathrm{NH}_{3}\right)$ resulting from pyrolysis of the fuel, with minor contributions from larger $\mathrm{N}$-containing organic species, especially at lower temperatures. Flame chemistry converts those species to $\mathrm{N}_{2}, \mathrm{~N}_{2} \mathrm{O}$, nitric oxide (NO), nitrogen dioxide $\left(\mathrm{NO}_{2}\right)$, and nitrous acid (HONO) as a result of radical chemistry. It has been recognized for some time that a significant amount of denitrification (conversion of $\mathrm{N}_{\mathrm{r}}$ compounds to $\mathrm{N}_{2}$ ) occurs due to reactions of $\mathrm{NO}$ with $\mathrm{NH}_{i}$ (where $i=1,2$, or 3 ) or $\mathrm{N}$ atoms, as confirmed experimentally (Kuhlbusch et al., 1991). While $\mathrm{N}$ atoms are also intermediates in the thermal $\mathrm{NO}_{x}$ cycle, and the reaction $\mathrm{N}+\mathrm{O}_{2} \rightarrow \mathrm{NO}+\mathrm{O}$ figures in to both the fuel and thermal $\mathrm{NO}_{x}$ cycles, the second reaction of the thermal $\mathrm{NO}_{x}$ cycle, $\mathrm{O}+\mathrm{N}_{2} \rightarrow \mathrm{NO}+\mathrm{N}$, is too slow at BB flame temperatures to result in $\mathrm{NO}_{x}$ production (Manion et al., 2015). In addition to the small molecules shown in Fig. 1, numerous $\mathrm{N}_{\mathrm{r}}$ compounds are emitted in roughly the following categories: amides, amines, heterocyclic compounds, nitriles, isocyanates, and nitro compounds (Andreae, 2019; Andreae and Merlet, 2001; Koss et al., 2018; Lobert et al., 1991, 1990; Lobert and Warnatz, 1993; Stockwell et al., 2015). These compounds are produced at much lower abundance from fuel pyrolysis and partial reactions with the radical species in Fig. 1.

The emissions of $\mathrm{N}$ compounds from $\mathrm{BB}$ and wildfires in general have been the subject of considerable research. Early studies by Lobert et al. (1990, 1991) and Lobert and Warnatz (1993) measured a wide range of $\mathrm{N}_{\mathrm{r}}$ compounds in laboratory fires and suggested that considerable denitrification (conversion of fuel nitrogen to $\mathrm{N}_{2}$ ) was taking place, a process later confirmed in experiments described by Kuhlbusch et al. (1991). Subsequent work on laboratory fires has betterdefined particle-phase nitrogen emissions (McMeeking et al., 2009) and led to the recognition of the importance of several inorganic $\mathrm{N}_{\mathrm{r}}$ species, such as HONO and HNCO (Burling et al., 2010; Roberts et al., 2011; Veres et al., 2010), and the presence of a wider variety of organic $\mathrm{N}_{\mathrm{r}}$ species (Gilman et al., 2015; Stockwell et al., 2015; Warneke et al., 2011). A number of studies have sought to summarize both realworld and laboratory emissions of $\mathrm{N}_{\mathrm{r}}$ compounds (Akagi et al., 2011; Andreae, 2019; Andreae and Merlet, 2001; Coggon et al., 2016; Yokelson et al., 2013b, 2009). The known N compounds range in oxidation state from $\mathrm{NH}_{3}$ to $\mathrm{HNO}_{3}$ and include $\mathrm{N}_{2}$ and $\mathrm{N}_{2} \mathrm{O}$. Among the more prominent and impor$\operatorname{tant} \mathrm{N}_{\mathrm{r}}$ species are the following: $\mathrm{NO}_{x}\left(\mathrm{NO}\right.$ and $\left.\mathrm{NO}_{2}\right)$, which is a key player in the atmospheric oxidant cycle; $\mathrm{NH}_{3}$, which has a major role in particle formation; HONO, which can be an important radical source; $\mathrm{HCN}$ and acetonitrile $\left(\mathrm{CH}_{3} \mathrm{CN}\right)$, which are toxic at high concentrations and represent valuable 


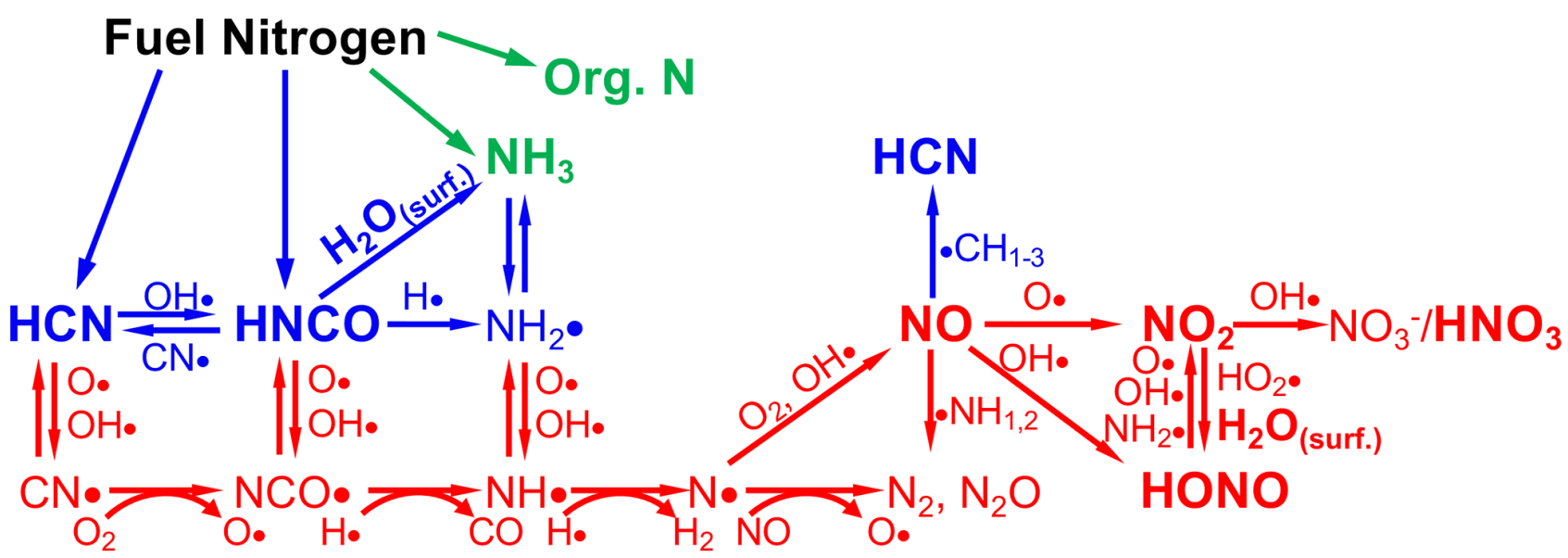

Figure 1. Schematic of the combustion chemistry of the small molecules that are emitted from BB and represent sources and sinks of reactive nitrogen $\left(\mathrm{N}_{\mathrm{r}}\right)$, adapted from Glarborg et al. (2018), Lobert and Warnatz (1993), Lucassen et al. (2012), and Manion et al. (2015). $\mathrm{H}_{2} \mathrm{O}_{(\text {surf) }}$ denotes the combination of $\mathrm{H}_{2} \mathrm{O}$ and a surface to facilitate the reaction. Red color indicates the highest temperature (combustion) processes; blue indicates intermediate temperature processes, and green indicates the lowest temperature processes. The species that are measured in this work are shown in bold and slightly larger text.

tracers for following fire transport; and isocyanates, $\mathrm{HNCO}$ and methyl isocyanate $\left(\mathrm{CH}_{3} \mathrm{NCO}\right)$, which have unique health impacts (Roberts et al., 2011). In addition, nitro $\left(\mathrm{R}-\mathrm{NO}_{2}\right)$ or nitrogen heterocyclic compounds may contribute to so-called brown carbon, aerosol organic compounds exhibiting optical absorption in the near-UV or blue wavelength regions. Wildfire $\mathrm{N}$ emissions also have very minor contributions from gas-phase nitric acid $\left(\mathrm{HNO}_{3}\right)$. Nitric acid is either not efficiently produced by $\mathrm{BB}$ or readily incorporated into aerosol if it is produced in fresh wildfire plumes, as is clear from the absence of $\mathrm{HNO}_{3}$ enhancements in several studies of BB plumes (Liu et al., 2016; Yokelson et al., 2009; Alvarado et al., 2010); however nitrate $\left(\mathrm{NO}_{3}^{-}\right)$has been shown to contribute to aerosol mass particularly for inefficient combustion (May et al., 2014). Flame chemistry is inefficient in forming $\mathrm{N}_{2} \mathrm{O}$, relative to the pathways that form $\mathrm{N}_{2}$ (Andreae, 2019; Andreae and Merlet, 2001; Griffith et al., 1991; Hao et al., 1991). The modeling of the emissions of these $\mathrm{N}$ compounds on a large scale could benefit from a better understanding of the total budget of these species as a function of fuel nitrogen content and the dependence of the individual species on fuel type and combustion conditions.

The construction of $\mathrm{N}_{\mathrm{r}}$ budgets in this work is made possible by the inclusion of a total reactive nitrogen measurement (termed $\mathrm{N}_{\mathrm{r}}$ herein), a method by which all nitrogen compounds besides $\mathrm{N}_{2}$ and $\mathrm{N}_{2} \mathrm{O}$ are converted to $\mathrm{NO}$ and detected by $\mathrm{NO}-\mathrm{O}_{3}$ chemiluminescence. This technology has been developed by a number of groups, typically using precious metal or $\mathrm{NiCr}$ catalysts that have been shown to convert all $\mathrm{N}_{\mathrm{r}}$ compounds to $\mathrm{NO}$ (and to some extent $\left.\mathrm{NO}_{2}\right)$ at high temperatures $\left(750-825^{\circ} \mathrm{C}\right)$ (Hardy and Knarr, 1982; Kashihira et al., 1982; Marx et al., 2012; Roberts et al., 1988). There are also commercial instruments that incor- porate this technology (see for example Thermo Scientific Model 17i). This technique has been applied to gas-phase atmospheric measurements, principally to measure $\mathrm{NH}_{3}$ by difference techniques (Saylor et al., 2010; Schwab et al., 2007), and has also been used to observe wildfire plumes that have impacted ambient air measurements (Benedict et al., 2017; Prenni et al., 2014). We have recently developed a platinum/molybdenum oxide $\mathrm{N}_{\mathrm{r}}$ catalyst system and confirmed that it quantitatively converts $\mathrm{N}_{\mathrm{r}}$ compounds including all particle-bound nitrogen compounds (Stockwell et al., 2018). To our knowledge this technique has not been applied directly to BB emissions before.

This paper describes the total reactive nitrogen and individual $\mathrm{N}_{\mathrm{r}}$ compound measurements made during the Fire Lab 2016 experiment, with the intent of providing information that can be used for analysis and modeling of the impact of wildfire emissions on the atmosphere. The total $\mathrm{N}_{\mathrm{r}}$ measurements are combined with $\mathrm{CO}_{2}, \mathrm{CO}$, and VOC measurements and fuel, residue, and ash $\mathrm{C}$ and $\mathrm{N}$ content to estimate the amount of $\mathrm{N}$ lost to $\mathrm{N}_{2}$ and $\mathrm{N}_{2} \mathrm{O}$. In addition systematics of the ratio $\mathrm{N}_{\mathrm{r}}$ / total carbon are examined for simplifying relationships. Fire-integrated $\mathrm{N}_{\mathrm{r}}$ is then compared to fireintegrated measurements of individual compounds to determine the fraction of unaccounted-for $\mathrm{N}_{\mathrm{r}}$. The systematic behavior of individual $\mathrm{N}_{\mathrm{r}}$ species and their fractional contribution to $\mathrm{N}_{\mathrm{r}}$ are examined with respect to fuel type, $\mathrm{N}$ content, and combustion processes. A positive matrix factorization (PMF) technique is used to examine commonalities between fires of different fuels under different conditions and compared to the PMF analysis of the VOC emissions published by Sekimoto et al. (2018). The results are used to arrive at suggested guidelines that can be used estimate $\mathrm{N}_{\mathrm{r}}$ emissions profiles for fires representative of western North America. 
Table 1. Nitrogen compounds observed in the FIREX Fire Lab 2016 Study.

\begin{tabular}{|c|c|c|c|}
\hline Compound/class & Importance & Measurement method & Method reference \\
\hline Total reactive $\mathrm{N}$ & $\begin{array}{l}\text { Total available for at- } \\
\text { mospheric reactions }\end{array}$ & $\begin{array}{l}\text { Catalytic conversion } \\
\mathrm{NO} / \mathrm{O}_{3} \text { chemilumines- } \\
\text { cence }\end{array}$ & Stockwell et al. (2018) \\
\hline \multirow[t]{2}{*}{ Nitric oxide } & $\begin{array}{l}\text { Major "flaming-stage" } \\
\text { product, oxidant pro- } \\
\text { duction }\end{array}$ & $\begin{array}{l}\mathrm{NO} / \mathrm{O}_{3} \text { chemilumines- } \\
\text { cence }\end{array}$ & Williams et al. (1998) \\
\hline & & $\begin{array}{lr}\text { OP-FTIR } & \text { (open-path } \\
\text { Fourier } & \text { transform } \\
\text { infrared) } & \end{array}$ & Selimovic et al. (2018) \\
\hline Nitrogen dioxide & $\begin{array}{l}\text { Atmospheric oxidant } \\
\text { production }\end{array}$ & $\begin{array}{l}\text { OP-FTIR, ACES (air- } \\
\text { borne cavity-enhanced } \\
\text { spectrometer) }\end{array}$ & $\begin{array}{l}\text { Stockwell et al. (2014), Min et } \\
\text { al. (2016), Zarzana et al. (2018) }\end{array}$ \\
\hline Nitrous acid & $\mathrm{HO}_{x}$ radical source & OP-FTIR, ACES & $\begin{array}{l}\text { Stockwell et al. (2014), Min et } \\
\text { al. (2016), Zarzana et al. (2018) }\end{array}$ \\
\hline Nitric acid ${ }^{\mathrm{a}}$ & Particle precursor & OP-FTIR & $\begin{array}{l}\text { Yokelson et al. (2009), } \\
\text { McMeeking et al. (2009) }\end{array}$ \\
\hline Hydrogen cyanide & $\begin{array}{l}\text { Flame chemistry, atmo- } \\
\text { spheric tracer, toxicity }\end{array}$ & $\begin{array}{l}\text { OP-FTIR, PTR-ToF- } \\
\text { MS (proton transfer } \\
\text { reaction time-of-flight } \\
\text { mass spectrometer) }\end{array}$ & $\begin{array}{l}\text { Selimovic et al. (2018), Koss et } \\
\text { al. (2018) }\end{array}$ \\
\hline Isocyanic acid & $\begin{array}{l}\text { Flame chemistry, toxic- } \\
\text { ity, health effects }\end{array}$ & PTR-ToF-MS & Koss et al. (2018) \\
\hline Ammonia & $\begin{array}{l}\text { Major "smoldering- } \\
\text { stage" product, main } \\
\text { atmospheric base, } \\
\text { particle formation }\end{array}$ & OP-FTIR & Selimovic et al. (2018) \\
\hline $\begin{array}{l}\text { NVOCs: } \\
\text { Amines }^{\mathrm{b}} \\
\text { Amides }^{\mathrm{c}} \\
\text { Heterocyclics }^{\mathrm{d}} \\
\text { Nitriles }^{\mathrm{e}} \\
\text { Nitro compounds }^{\mathrm{f}}\end{array}$ & $\begin{array}{l}\text { Brown carbon, toxicity, } \\
\text { tracers }\end{array}$ & $\begin{array}{l}\text { PTR-ToF-MS, GC/MS } \\
\text { (gas chromatography } \\
\text { mass spectrometry), } \\
\mathrm{I}^{-} \text {CIMS (iodide ion } \\
\text { chemical ionization } \\
\text { mass spectrometer. }\end{array}$ & $\begin{array}{l}\text { Koss et al. (2018) } \\
\text { Gilman et al. (2015) } \\
\text { Lerner et al. (2017) } \\
\text { B. H. Lee et al. (2014) }\end{array}$ \\
\hline $\begin{array}{l}\text { The OP-FTIR has a } 10 \mathrm{pp} \\
\text { Ethylamine, methanimin } \\
\text { Formamide, acetamide, } \mathrm{n} \\
\mathrm{C}_{2} \text {-pyrroles, dihydropyri } \\
\text { Acetonitrile, acrylonitrile } \\
\text { ethylbenzoacetonitrile, } \mathrm{p} \\
\text { Butenenitrates, nitrobenz }\end{array}$ & $\begin{array}{l}\text { on for gas-phase } \mathrm{HNO}_{3} \text {, but } \mathrm{HI} \\
\text { amine, sulfinylmethanamine, tri } \\
\text { eimide. } \\
\text { nylpyrrole, methylpyridine, met } \\
\text { rile, butanenitrile, butynenitrile } \\
\text { es, propanenitrile, propynenitril }\end{array}$ & $\begin{array}{l}3 \text { was not observed above detecti } \\
\text { thylamine, buteneamines. } \\
\text { Ipyrrole, pyridinealdehyde, 4-pyr } \\
\text { enzoacetonitrile, } C_{7} \text { acrylonitrile, } \\
\text { utenenitrile, methylisocyanate. }\end{array}$ & $\begin{array}{l}\text { n limit. } \\
\text { Idinol, vinylpyridine. } \\
\text {-8-nitriles, heptylnitrile, furancarbonitrile, }\end{array}$ \\
\hline
\end{tabular}

\section{Methodology}

The Fire Lab 2016 study involved laboratory burns of fuels mostly characteristic of western North American wildfires such as coniferous fuels and chaparral fuels (important in central to southern California and the southwestern US). We also measured some that have global significance such as Indonesian peat and yak dung (important in areas above timberline or where wood is scarce, such as India, Nepal, and Tibet). The procedures and associated details of the study have been described previously by Selimovic et al. (2018) and will be only briefly summarized here. The detailed data on fuel types, amounts, and composition can be found in Table S1 in the Supplement and in the Supplement of Selimovic et al. (2018). The laboratory burns involved fuel samples, ranging in mass from 0.26 to $6.02 \mathrm{~kg}$ spread out on a fuel bed roughly $1 \mathrm{~m} \times 1 \mathrm{~m}$ square. Fires were started without the addition of any contaminants, using an electric igniter (a series of $\mathrm{NiCr}$ heating elements that were flash-heated electrically), and typically lasted from approximately 5 to $30 \mathrm{~min}$. 
Seventy-five fires were conducted in the "stack" burn configuration where the smoke was directed up the central stack of the facility where it could be sampled simultaneously by all the instruments that measured gas-phase species and some of the particle-phase measurements. The sampling platform was about $15 \mathrm{~m}$ above the fire, and the sampling took place in well-mixed smoke approximately $5 \mathrm{~s}$ after emission (Christian et al., 2003). Thirty-one additional fires were conducted as "room" burns on most of the same fuels, when the stack was closed and the room was allowed to fill with smoke, permitting sampling to be done over the course of several hours. The following analyses will focus on the stack burns, as those measurements had little or no interferences from surfaces, where room burns are known to be compromised by the loss of materials, such as $\mathrm{NH}_{3}$, to the room walls at long sample times (Stockwell et al., 2014). Ash analyses were performed only on the residues from the room burns, and those values will be used for the $\mathrm{N}$ and $\mathrm{C}$ budget calculations, with the assumption that stack and room burns left similar ash, considering the combustion conditions were the same for each type of fire. Table 1 lists the compounds and associated techniques used to measure them during the Fire Lab 2016 study and describes the grouping of NVOCs measured by a proton transfer reaction time of flight mass spectrometer (PTRToF-MS) into common categories, e.g., amines, nitriles, etc. We specifically note that the OP-FTIR is capable of measuring gas-phase $\mathrm{HNO}_{3}$ with comparatively good sensitivity ( 10 ppbv detection limit in fires where $\mathrm{N}_{\mathrm{r}}$ can be 5 ppmv or more), but $\mathrm{HNO}_{3}$ was not observed above detection limit in any of the fires.

\section{1 $\mathrm{N}_{\mathrm{r}}$ and NO measurements by chemiluminescence}

Total reactive $\mathrm{N}\left(\mathrm{N}_{\mathrm{r}}\right)$ was measured by catalytic conversion to $\mathrm{NO}$, followed by $\mathrm{O}_{3}$ chemiluminescence using an instrument described previously (Williams et al., 1998). $\mathrm{N}_{\mathrm{r}}$ and NO were sampled from inlets inserted adjacent to the inlet-less openpath Fourier transform infrared spectrometer (OP-FTIR) instrument path during the stack burns (Selimovic et al., 2018) and from a platform approximately $4 \mathrm{~m}$ off the floor in the middle of the room during the room burns. The catalyst used for the $\mathrm{N}_{\mathrm{r}}$ channel, described in detail by Stockwell et al. (2018), consisted of a $11 \mathrm{~mm}$ i.d. quartz tube, packed with 36 platinum screens, heated to $750^{\circ} \mathrm{C}$. This tube was wrapped with high-temperature heating tape and insulated inside a $7 \mathrm{~cm}$ o.d. stainless steel tube that was fitted to a bulkhead placed through the wall of the stack. The $\mathrm{N}_{\mathrm{r}}$ channel was diluted by a factor of $5: 1( \pm 3 \%)$ using a flow of zero air added immediately downstream of the Pt catalyst assembly. NO was sampled through a $6.3 \mathrm{~mm}$ o.d. stainless steel inlet tube, which was placed through the bulkhead directly into the free air stream of the stack and connected to a $50 \mathrm{~mm}$ Teflon filter holder immediately outside the stack. The transfer lines for the $\mathrm{N}_{\mathrm{r}}$ and $\mathrm{NO}$ measurements consisted of $6.35 \mathrm{~mm}$ o.d., $1 \mathrm{~mm}$ wall thickness PFA tubing of approximately $20 \mathrm{~m}$ in length. $\mathrm{N}_{\mathrm{r}}$ and $\mathrm{NO}$ data were acquired at $1 \mathrm{~s}$ frequency, but the flow rate through each inlet was $1 \mathrm{SL} \mathrm{min}{ }^{-1}$, resulting in residence time in each inlet of $14 \mathrm{~s}$. This time delay was corrected in the data analysis. Any chemical effects of the inlet on the sampled air stream were negligible since the analytes consisted of only $\mathrm{NO}$ and $\mathrm{NO}_{2}$, and those are known to be transmitted by PFA Teflon tubing with essentially no surface effects. However, there were possible effects of the inlets on the temporal features of the measurement through diffusion or turbulent mixing. Those effects were examined through comparison of the temporal variations in the NO signal with the NO measured by the OP-FTIR and comparison of the $\mathrm{N}_{\mathrm{r}}$ signal under smoldering conditions with the $\mathrm{NH}_{3}$ measured by the OP-FTIR. Both of these comparisons showed that the $\mathrm{NO}$ and $\mathrm{N}_{\mathrm{r}}$ inlets had effective time constants of $4 \mathrm{~s}$, somewhat slower than the diffusive relaxation time assuming solely laminar flow. Examples of the estimate of diffusion and dispersion on $\mathrm{NO}$ and $\mathrm{N}_{\mathrm{r}}$ signals and the estimate of the effective time constant of these measurements are presented in the Supplement.

The inlet streams were sampled by the NO instrument either directly (NO channel) or after passing through a second catalyst of molybdenum oxide (MoOx) to convert remaining $\mathrm{NO}_{2}$ to NO. The MoOx catalyst consisted of a molybdenum tube at $350{ }^{\circ} \mathrm{C}$ to which a small flow of $\mathrm{H}_{2}(0.8 \% \mathrm{v} / \mathrm{v})$ was added to control the redox state of the surface. Both channels of the instrument were "detuned" to keep raw photon count rates below $4 \mathrm{MHz}$, by turning down the $\mathrm{O}_{3}$ flows and photo-multiplier tube (PMT) voltages. Calibrations were performed with both a NO standard in $\mathrm{N}_{2}$ (Scott-Marrin) and 10.1 ppmv standard of $\mathrm{HCN}$ in nitrogen (Gasco). The Pt catalyst was dismounted from the stack (or room) every few days and checked for conversion efficiency by the addition of the HCN standard to the inlet. Conversion efficiencies were found to be consistently high (> $98 \%$ ) throughout the entire sampling period (5 October-12 November 2016). There were slight background signals (a few tens of ppbv) for both NO and $\mathrm{N}_{\mathrm{r}}$ in both the stack and room air prior to and after the burns, and those were subtracted from the fires' signals prior to reporting the data. The overall uncertainties in the NO and $\mathrm{N}_{\mathrm{r}}$ data were $\pm 10 \%$ for each measurement.

\subsection{Other measurements}

Measurements of individual species during the 2016 Fire Lab study have been presented in several previous publications. The OP-FTIR measurements were discussed by Selimovic et al. (2018), and the PTR-ToF measurements were discussed by Koss et al. (2018). In addition, some of the calibration methods and GC separation and identifications rely on additional analytical work presented by Sekimoto et al. (2017) and Gilman et al. (2015). We measured the mass and elemental content of the initial fuel and the mass of unburned fuel for all the fires, and we measured the mass and the elemental 
Table 2. Compounds and compound classes used in the PMF analyses and their corresponding errors.

\begin{tabular}{lll}
\hline Compound or class & Unit & Estimated error \\
\hline $\mathrm{NH}_{3}$ & ppbv & $5 \%+2 \mathrm{ppbv}$ \\
$\mathrm{NO}$ & ppbv & $10 \%+1 \mathrm{ppbv}$ \\
$\mathrm{NO}_{2}$ & ppbv & $10 \%+0.2 \mathrm{ppbv}$ \\
$\mathrm{HONO}$ & $\mathrm{ppbv}$ & $20 \%+1 \mathrm{ppbv}$ \\
$\mathrm{HCN}$ & $\mathrm{ppbv}$ & $15 \%+0.2 \mathrm{ppbv}$ \\
$\mathrm{HNCO}$ & $\mathrm{ppbv}$ & $15 \%+0.2 \mathrm{ppbv}$ \\
Nitriles & ppbv & $20 \%+0.2 \mathrm{ppbv}$ \\
Amines & ppbv & $20 \%+0.2 \mathrm{ppbv}$ \\
Amides & ppbv & $20 \%+0.2 \mathrm{ppbv}$ \\
Nitro compounds & ppbv & $20 \%+0.2 \mathrm{ppbv}$ \\
Heterocyclics & ppbv & $20 \%+0.2 \mathrm{ppbv}$ \\
\hline
\end{tabular}

content of the ash during 21 room burns, which covered all the fuel types discussed.

\subsection{PMF analysis}

Trace gas measurements from multiple instruments involved in the Fire Lab study were combined and analyzed using positive matrix factorization (PMF). PMF is a numerical method that was used in this case to partition the compounds involved in a time-varying mixture of chemicals into a few groups, or "factors", where a compound can appear in more than one factor. A factor represents a consistent profile of compounds that is representative of one of the sources contributing to the total signal. The sum of all the factors then ideally describes the total composition of the measurements, which in this case is the emissions of $\mathrm{N}_{\mathrm{r}}$ compounds. By its nature, PMF assumes that the total signal is a linear combination of individual sources that have a consistent composition, the relative contribution of which is represented by the amount of each compound or category found in each factor (Paatero and Tapper, 1994; Ulbrich et al., 2009). We hypothesize that species with dominant fractions in the same factor are related to each other via the same formation processes. With knowledge of factor composition and the amount of each factor at any given time, the original emissions measurements can be reconstructed, and this approach provides an alternate source of profiles for fire emissions. PMF has also been used by a number of groups to explore how much various source profiles contribute to complex ambient measurements (see for example Ulbrich et al., 2009) and was recently used to analyze PTR-ToF-MS measurements from the Fire Lab (Sekimoto et al., 2018). Here, PMF was accomplished using the PMF Evaluation Tool v. 2.08A (Ulbrich et al., 2009).

The application of PMF to this data set is different than the instances where it is applied to data from a single instrument in which compound abundances are inherently scaled properly and error estimates are well defined and self-consistent. For example, when applied to mass spectral data from a sin- gle instrument, errors can be expected to scale as the square root of ion counts based on fundamental counting statistics (Sekimoto et al., 2018). In this work we are including nitrogen measurements from several instruments, and thus we chose to use mixing ratios as the unit of comparison. The error estimates required by the PMF analysis were taken from the reported combined uncertainties: the sum of the detection limit plus the estimated random error of the measured value. For example, the uncertainty in a NO mixing ratio of 500 ppbv was \pm 51 ppbv. The variables that were used in this PMF analysis and their units and corresponding errors are listed in Table 2. Where compound categories are specified (e.g., nitriles), the values were the sum of the measured compounds in that category as listed in the footnotes of Table 1. The data were further adjusted by subtracting the ambient air background before and after the fires, which was a relatively minor adjustment for most compounds and categories. Any negative numbers that resulted were very small compared to the fire emissions and were set to zero. In addition to the PMF analysis for the species listed in Table 2, several exploratory runs were tried with $\mathrm{CO}_{2}, \mathrm{CO}$ added (in units of ppmv), and total $\mathrm{N}_{\mathrm{r}}$ (in units of ppbv) added to the list in Table 2. No significant differences were observed in the results for individual $\mathrm{N}_{\mathrm{r}}$ compounds and classes, so $\mathrm{CO}_{2}, \mathrm{CO}$, and total $\mathrm{N}_{\mathrm{r}}$ were not included in this analysis.

We applied PMF to single-fire data as well as extended time series that included all fires of a particular fuel type, in line with the approach laid out by Sekimoto et al. (2018). By consolidating fuels from a particular vegetation type, the fire-to-fire variability largely driven by differences in the fuel (e.g., moisture content, structure, quantity) is constrained and the most representative fire conditions are captured. Two fuel groups were analyzed in this way: the western US coniferous ecosystem fuels, which included ponderosa pine, lodgepole pine, Douglas fir, Engelmann spruce, and subalpine fir, and the southwestern US chaparral ecosystem, which was represented by chamise and manzanita. The consolidated time series for the coniferous ecosystems included realistic mixtures, canopy only, and litter only, while duff and rotten logs were analyzed separately and not included in the time series.

\section{Results and discussion}

The measurements of total $\mathrm{N}_{\mathrm{r}}$ can be combined with $\mathrm{N}$ and $\mathrm{C}$ measurements of fuel and ash to estimate $\mathrm{N}$ lost to $\mathrm{N}_{2}$ and $\mathrm{N}_{2} \mathrm{O}$. The total $\mathrm{N}_{\mathrm{r}}$ emitted from laboratory fires combined with individual $\mathrm{N}$ compound measurements allow us to construct a budget for $\mathrm{N}_{\mathrm{r}}$ species that define what the dominant forms of $\mathrm{N}$ are and how those emissions depend on other fire parameters or different temperature combustion processes. The systematics of $\mathrm{N}$ emissions found by PMF are compared to other fire indicators, and PMF analyses previously conducted on VOCs allow the formulation of simplifying relationships that can be used in atmospheric models of wildfires. 


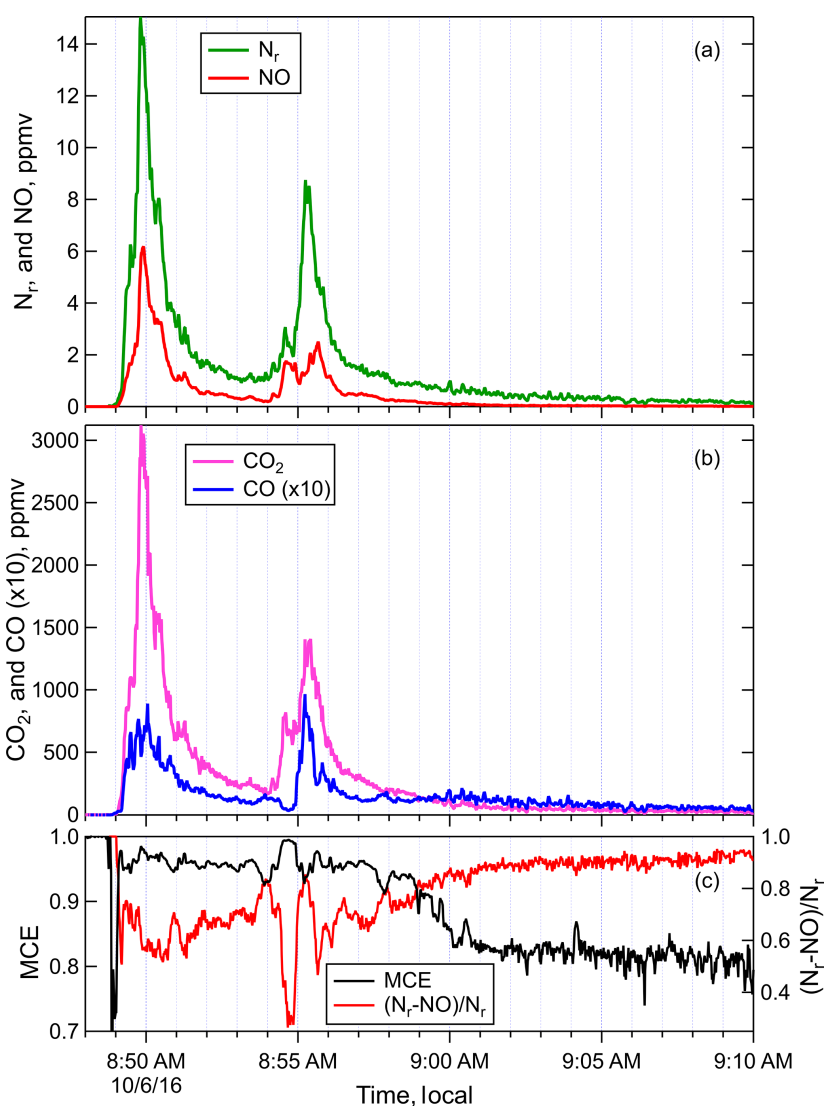

Figure 2. Timelines of the (a) $\mathrm{N}_{\mathrm{r}}$ and $\mathrm{NO}$, (b) $\Delta \mathrm{CO}_{2}$ and $\Delta \mathrm{CO}$, and (c) MCE and $\left(\mathrm{N}_{\mathrm{r}}-\mathrm{NO}\right) / \mathrm{N}_{\mathrm{r}}$ measured during Fire 004, a ponderosa pine realistic mix sample. Note that $\Delta \mathrm{CO}$ is plotted at $\times 10$ the measured abundance for clarity.

\subsection{Comparison of $\mathrm{N}_{\mathrm{r}}$ and total carbon in fire emissions}

The total $\mathrm{N}_{\mathrm{r}}$ and total carbon emissions were measured for 75 stack fires in order to place the $\mathrm{N}$ emissions in the context of total carbon, which has been widely estimated for wildfires. Example time series of $\mathrm{NO}, \mathrm{N}_{\mathrm{r}}, \Delta \mathrm{CO}$, and $\Delta \mathrm{CO}_{2}$ ( $\mathrm{CO}$ and $\mathrm{CO}_{2}$ corrected for their backgrounds) are shown in Fig. 2, for a fire burning a sample of ponderosa pine realistic mix (Fire 004). In addition to the chemical species, the modified combustion efficiency (MCE) was also plotted. MCE is defined as

$\mathrm{MCE}=\Delta \mathrm{CO}_{2} /\left(\Delta \mathrm{CO}_{2}+\Delta \mathrm{CO}\right)$,

where $\Delta \mathrm{CO}_{2}$ and $\Delta \mathrm{CO}$ are the $\mathrm{CO}_{2}$ and $\mathrm{CO}$ levels above the ambient. MCE has traditionally been used to indicate the relative amount of flaming and smoldering combustion in a fire. The time series for Fire 004 (Fig. 2) shows a short initial smoldering/distillation phase (MCE 0.7 to 0.8 ) as heat pyrolyzes the fresh fuel and releases VOCs from existing pools in the fuel, followed after ignition by a relatively efficient mix of flaming and smoldering combustion (MCE 0.95 to 0.98) and then finally a subsequent period of essentially pure smol- dering (MCE 0.80). The $\mathrm{N}_{\mathrm{r}}$ and $\mathrm{NO}$ timelines had many features in common because NO is often the most abundant $\mathrm{N}_{\mathrm{r}}$ compound (see below). As a result, it is useful to compare the quantities $\mathrm{N}_{\mathrm{r}}-\mathrm{NO}$ and $\left(\mathrm{N}_{\mathrm{r}}-\mathrm{NO}\right) / \mathrm{N}_{\mathrm{r}}$ to the other measures of chemical species or combustion efficiency. As expected, $\left(\mathrm{N}_{\mathrm{r}}-\mathrm{NO}\right) / \mathrm{N}_{\mathrm{r}}$, in Fig. $2 \mathrm{c}$ is anticorrelated with MCE since $\mathrm{N}_{\mathrm{r}}$ is primarily $\mathrm{NO}$ at high MCE. In addition to the anticorrelation, this non-NO fraction, like its approximate carbon analog $\mathrm{CO} / \mathrm{CO}_{2}$, has a wider dynamic range than $\mathrm{MCE}$ and will often suffer less from background variability than carbon-based indices (Yokelson et al., 2013a).

The concentration profiles of the background-corrected measurements of $\mathrm{N}_{\mathrm{r}}, \mathrm{CO}_{2}, \mathrm{CO}$, and all the carbon-containing species measured by the FTIR (Selimovic et al., 2018) during the stack burns were integrated over the entire time of the burn to obtain total carbon, termed TC here, and total $\mathrm{N}_{\mathrm{r}}$. The additional carbon species included methane and a number of other gas phase VOCs as well as organic- and black-carbon aerosol. Altogether these carbon species should account for $\geq 98 \%$ of emitted carbon (McMeeking et al., 2009). Total $\mathrm{N}_{\mathrm{r}}$ is plotted in Fig. 3, versus TC (Fig. 3a) and versus nitrogen burned, which is calculated from the $\% \mathrm{~N}$ in the fuel times the mass of fuel consumed (Fig. 3b). The points in Fig. 3 are colored by the fuel N/C mole \% obtained from the elemental analysis of each fuel. The relationship between $\mathrm{N}_{\mathrm{r}}$ and TC in Fig. 3a clusters around the $0.37 \%$ line, and those points are from fuels most characteristic of the North American biomes impacted by wildfire. There are clear outliers in the correlation of $\mathrm{N}_{\mathrm{r}}$ and TC; for example, yak dung and two samples of duff (Engelmann spruce and subalpine fir) were high due to the fact that they either have high fuel N/C ratios (dung; see Table S1 in the Supplement) or burned with minimal flaming (whole-fire MCEs 0.86-0.89, duff and dung), hence experienced less denitrification. The fuels that were low in $\mathrm{N}_{\mathrm{r}} / \mathrm{TC}$ in Fig. 3a, ponderosa pine rotten log, subalpine fir, and excelsior, had low fuel N/C, so when plotted versus nitrogen burned in Fig. 3b, they cluster with the main group of characteristic fuels, i.e., they are no longer "outliers" in the distribution.

\subsection{Estimates of denitrification}

The removal of $\mathrm{N}$ to forms that are inactive in the troposphere, $\mathrm{N}_{2}$ and $\mathrm{N}_{2} \mathrm{O}$, has importance in the biogeochemistry of forest ecosystems and also determines how much $\mathrm{N}$ takes part in wildfire plume chemistry. The points in Fig. 3a are all lower than the corresponding fuel N/C mole ratio, due to the denitrification chemistry, shown in Fig. 1 and verified in lab studies described by Kuhlbusch et al. (1991), and the production of $\mathrm{N}_{2} \mathrm{O}$, which is also not measured by the $\mathrm{N}_{\mathrm{r}}$ technique. The sum of $\mathrm{N}_{2}$ and $\mathrm{N}_{2} \mathrm{O}$ produced in the fires can be estimated from the difference between the fuel $\mathrm{N} / \mathrm{C}$ and the $\mathrm{N}_{\mathrm{r}}$ /total C emitted and the data on $\mathrm{C}$ and $\mathrm{N}$ content remaining in the ash. The mass balance equations used for these calculations are detailed in the Supplement. 


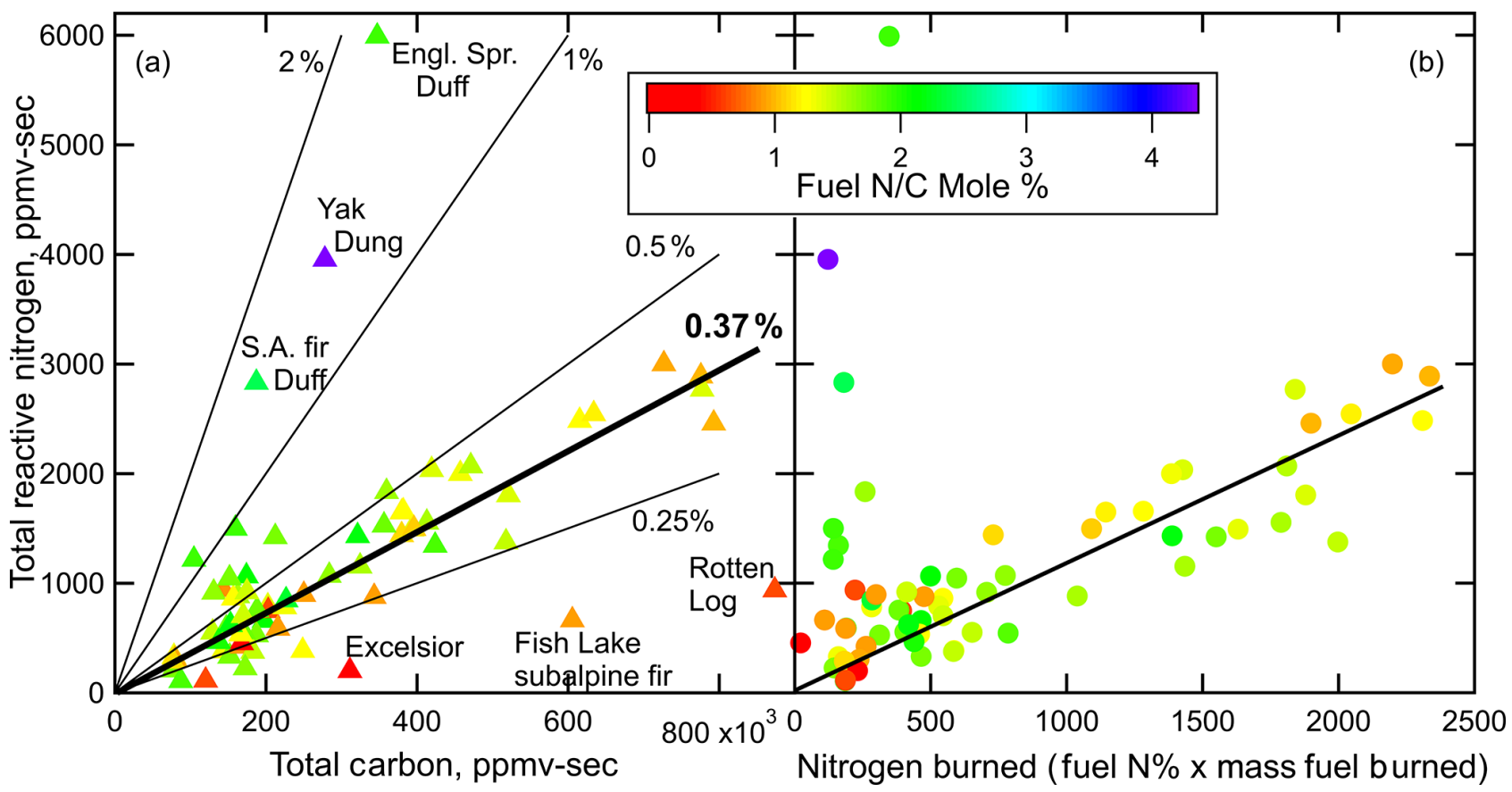

Figure 3. Integrated $\mathrm{N}_{\mathrm{r}}$ versus (a) integrated total carbon and versus (b) nitrogen burned, based on fuel nitrogen content and mass of fuel burned. The points are colored by fuel nitrogen to carbon ratio. Note that the $x$ and $y$ scales in panel (a) are different by more than a factor of 100 .

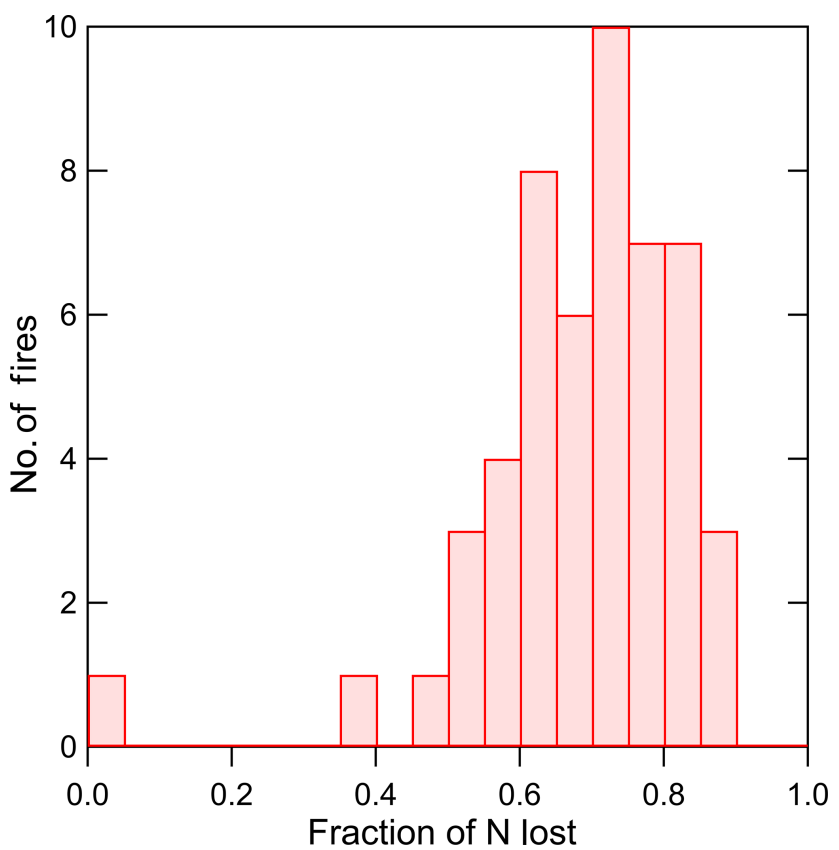

Figure 4. The histogram of the fraction of $\mathrm{N}$ loss to $\mathrm{N}_{2}$ and $\mathrm{N}_{2} \mathrm{O}$ estimated from the mass balance analysis described in the Supplement (52 burns).
The distribution of the $\mathrm{N}$ lost to $\mathrm{N}_{2}$ and $\mathrm{N}_{2} \mathrm{O}$ is shown in Fig. 4. Chemical analyses were not done for all fuels during the stack burns, and the analysis above assumes that the ash residues and ash / burned fuel ratios from the stack burns were well represented by those for the same fuels used in the room burns, for which mass yields and chemical analyses were done. Data are missing for fuels that did not have a corresponding residue analysis. The median fraction of $\mathrm{N}$ lost to $\mathrm{N}_{2}$ and $\mathrm{N}_{2} \mathrm{O}$ for ash-corrected fires was 0.70 , and the mean ( \pm standard deviation) was $0.68( \pm 0.14)$. This fuelbased estimate is uncertain by approximately $25 \%$ because of the above assumptions concerning the applicability of the residue analyses from the room burns and because fuel moisture corrections were assumed to apply to all of the materials burned, foliage vs. woody biomass (see the Supplement for details). The emission of $\mathrm{N}_{2} \mathrm{O}$ relative to $\mathrm{N}_{2}$ is approximately $10 \%$ or less for a wide range of fuels (Andreae, 2019). Assuming the $\mathrm{N}$ remainder in our work is at least $90 \% \mathrm{~N}_{2}$ gives values that are somewhat higher than the $\mathrm{N}_{2}$ values reported by Kuhlbusch et al. (1991) where $\mathrm{N}_{2}$ accounted for $36 \%$ of fuel $\mathrm{N}$ burned in flaming-stage fires. A closer inspection of Kuhlbusch et al. (1991) showed a range of $\mathrm{N}_{2}$ yields of $40 \%-54 \%$ at highest MCEs of $0.94-0.97$. Possible reasons for these differences are that the Kuhlbusch et al. (1991) fires were limited to grasses, hay, and pine needles, and the fires were confined to a closed container and so may not have experienced the convection and turbulence of typical biomass fires. In addition, the fires analyzed in our 


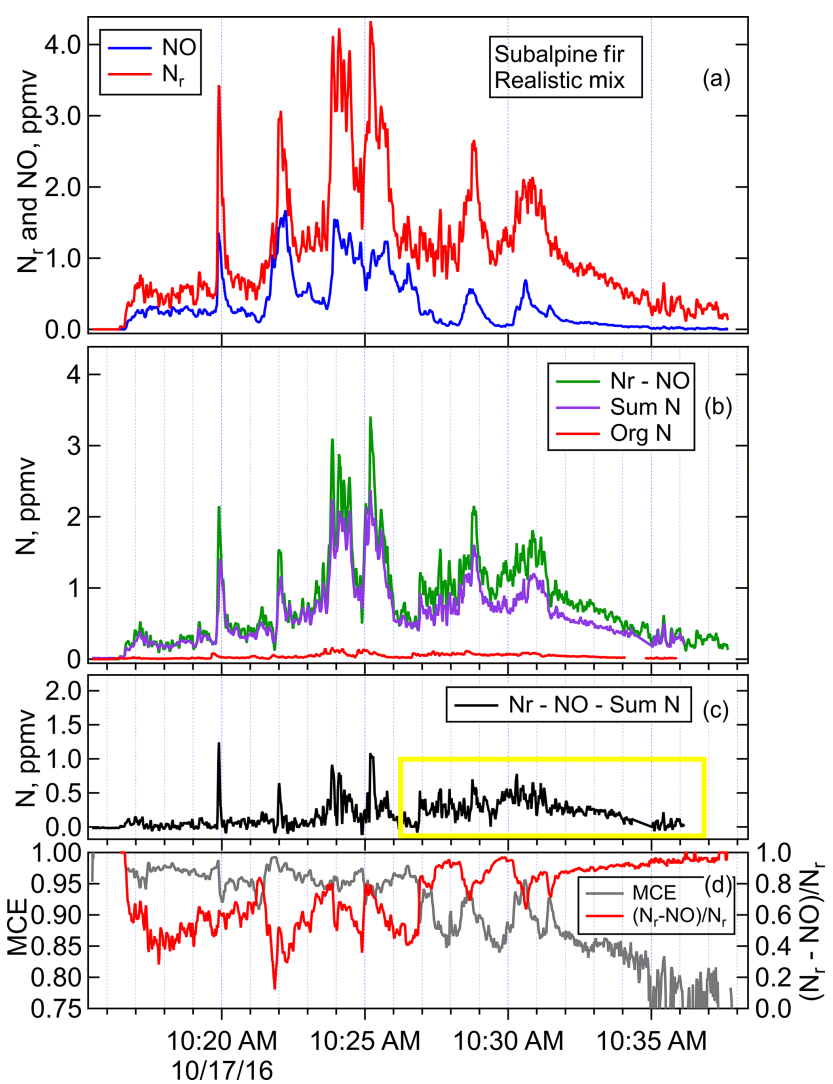

Figure 5. Timelines of (a) $\mathrm{N}_{\mathrm{r}}$ and $\mathrm{NO}$, (b) $\mathrm{N}_{\mathrm{r}}$ minus $\mathrm{NO}$ and the sum of all measures $\mathrm{N}$ species except for $\mathrm{NO}$, (c) residual of $\mathrm{N}_{\mathrm{r}}$ minus all measured $\mathrm{N}$ species $\left(\mathrm{N}_{\mathrm{r}}-\mathrm{NO}-\mathrm{Sum} \mathrm{N}\right),(\mathbf{d})$ and $\mathrm{MCE}$ and $\left(\mathrm{N}_{\mathrm{r}}-\mathrm{NO}\right) / \mathrm{N}_{\mathrm{r}}$ for Fire 047, subalpine fir realistic mix. The yellow box highlights the area of higher residual $\mathrm{N}_{\mathrm{r}}$ that corresponds to more smoldering emissions.

work were somewhat weighted towards the full canopy and higher temperature burning fuels, since ash analyses were not done for peat, dung, and many of the "litter" samples, all of which tend to burn less efficiently. Goode et al. (1999) estimated an $\mathrm{N}_{2}$ emission of $45 \pm 5 \%$ for MCE values of 0.95 in grass and surface fuels. The range of values determined in our work overlap with these literature values but are on average higher. It should be noted that such loss of reactive nitrogen can have implications for ecosystem $\mathrm{N}$ budgets, as discussed by Kuhlbusch et al. (1991).

\subsection{The budget of $\mathrm{N}_{\mathrm{r}}$ and individual $\mathrm{N}$-containing species}

The composition of the $\mathrm{N}$ that does not get converted to $\mathrm{N}_{2}$ or $\mathrm{N}_{2} \mathrm{O}$ is of intense importance in determining atmospheric impacts of fires, since those compounds are involved in oxidation capacity $\left(\mathrm{NO}_{x}\right)$, radical production $(\mathrm{HONO})$, and particle formation $\left(\mathrm{NH}_{3}\right)$. Emission factors (EF, defined as mass of compound emitted per mass of fuel burn) for all the individual $\mathrm{N}_{\mathrm{r}}$ compounds identified in our work have been com- piled and reported in previous publications (Koss et al., 2018; Selimovic et al., 2018), so this paper will focus on the $\mathrm{N}_{\mathrm{r}}$ budget. The balance of $\mathrm{N}_{\mathrm{r}}$ budget for Fire 047, subalpine fir realistic mix, is shown in Fig. 5, in which the timelines of $\mathrm{N}_{\mathrm{r}}, \mathrm{NO}, \mathrm{N}_{\mathrm{r}}-\mathrm{NO}$, sumN, and NVOC are plotted along with MCE and $\left(\mathrm{N}_{\mathrm{r}}-\mathrm{NO}\right) / \mathrm{N}_{\mathrm{r}}$. The quantity sumN is the sum of all other non-NO compounds, and NVOC is the subset of sumN that are organic nitrogen compounds measured by the PTRToF, as listed in Table 1. This fire had a mixture of flaming and smoldering combustion throughout the fire as indicated by MCE and nitrogen profiles (Fig. 5d). The comparison of $\mathrm{N}_{\mathrm{r}}-\mathrm{NO}$ with the sumN in Fig. $5 \mathrm{~b}$ shows that much of the $\mathrm{N}$ is accounted for. The major contributors to sumN for this fire were $\mathrm{HNCO}, \mathrm{HCN}, \mathrm{HONO}, \mathrm{NO}_{2}$, and $\mathrm{NH}_{3}$, while NVOC was a very small contributor to sumN (Fig. 5b). Note that while $\mathrm{HNO}_{3}$ is measurable by FTIR with good sensitivity, no $\mathrm{HNO}_{3}$ signals were observed above detection limit, which was 10 ppbv. Fig. 5c shows the residual left after NO and sumN are subtracted from $\mathrm{N}_{\mathrm{r}}$, corresponding to an integrated amount of $15.6 \pm 8 \%$ of $\mathrm{N}_{\mathrm{r}}$. This residual is reasonable, considering typical published particle $\mathrm{N}_{\mathrm{r}}$ measurements (Akagi et al., 2012, 2011; Liu et al., 2017; May et al., 2014), and consistent with there being some particle $\mathrm{N}_{\mathrm{r}}$ from flaming, which is most likely organic nitrates or nitro-organics, and particle ammonium from smoldering with potassium or ammonium nitrate, potentially accounting for substantial $\mathrm{N}_{\mathrm{r}}$.

Several fuels had much lower NO emissions and higher unaccounted-for $\mathrm{N}_{\mathrm{r}}$. Yak dung was one such fuel, the emissions of which stand in contrast to the fire shown above. The nitrogen emissions from Fire 050, yak dung, are shown in Fig. S2 in the Supplement. This fuel produced mostly smoldering emissions as exemplified by the low NO levels relative to $\mathrm{N}_{\mathrm{r}}$ (panel a) and the low MCEs observed (panel d). The sum of $\mathrm{N}_{\mathrm{r}}$ species was somewhat correlated with the quantity $\mathrm{N}_{\mathrm{r}}-\mathrm{NO}$ but was substantially lower, and the residual $\mathrm{N}_{\mathrm{r}}$ unaccounted for by the gas-phase measurements was $33.9 \pm 16 \%$ of $\mathrm{N}_{\mathrm{r}}$ (panel c). The majority of sumN was represented by $\mathrm{HCN}$ and $\mathrm{NH}_{3}$, with acetonitrile $\left(\mathrm{CH}_{3} \mathrm{CN}\right)$ higher than any of the other inorganics, $\mathrm{HNCO}, \mathrm{NO}_{2}$, or $\mathrm{HONO}$. The NVOCs were also a larger fraction of $\mathrm{N}_{\mathrm{r}}-\mathrm{NO}$ than in the case of Fire 047 shown above, a feature that implies that more semivolatile organic compounds (SVOCs) survive these types of fires and could make a proportionally higher contribution to the $\mathrm{N}_{\mathrm{r}}$ budget in this fire relative to Fire 047 . Fire Lab results of particle organic carbon measurements (Jen et al., 2019) and field measurements in environments with a lot of dung burning (Jayarathne et al., 2018; Stockwell et al., 2016a) are consistent with a higher EF for particle organic carbon and by extension particle NVOC compounds. The quantity $\left(\mathrm{N}_{\mathrm{r}}-\mathrm{NO}\right) / \mathrm{N}_{\mathrm{r}}$ was relatively high and had less dynamic range than for fires with more flaming combustion like Fire 047.

An overall budget of $\mathrm{N}_{\mathrm{r}}$ can be constructed for all of the stack fires through integrating the time profile of all the compounds and compound classes. The fire-integrated measure- 
Table 3. Summary of $X_{i} / \mathrm{N}_{\mathrm{r}}$ measurements for all stack burns ${ }^{\mathrm{a}}$.

\begin{tabular}{lr}
\hline Quantity & Average $\pm(\mathrm{SD}) \%$ \\
\hline $\mathrm{NO} / \mathrm{N}_{\mathrm{r}}$ & $34.5(16.6)$ \\
$\mathrm{NO}_{2} / \mathrm{N}_{\mathrm{r}}$ & $9.4(6.2)$ \\
$\mathrm{HNCO} / \mathrm{N}_{\mathrm{r}}$ & $6.0(2.9)$ \\
$\mathrm{HONO} / \mathrm{N}_{\mathrm{r}}$ & $4.5(2.2)$ \\
$\mathrm{HCN} / \mathrm{N}_{\mathrm{r}}$ & $4.3(2.3)$ \\
$\mathrm{NH}_{3} / \mathrm{N}_{\mathrm{r}}$ & $19.3(6.7)$ \\
$\mathrm{NVOC}_{\mathrm{r}}$ & $4.3(2.8)$ \\
$\left(\mathrm{N}_{\mathrm{r}}-\right.$ sumN) $/ \mathrm{N}_{\mathrm{r}}$ & $15.2(9.8)$ \\
\hline
\end{tabular}

a Not every measurement was available for every fire; consequently the values do not add up to exactly $100 \%$.

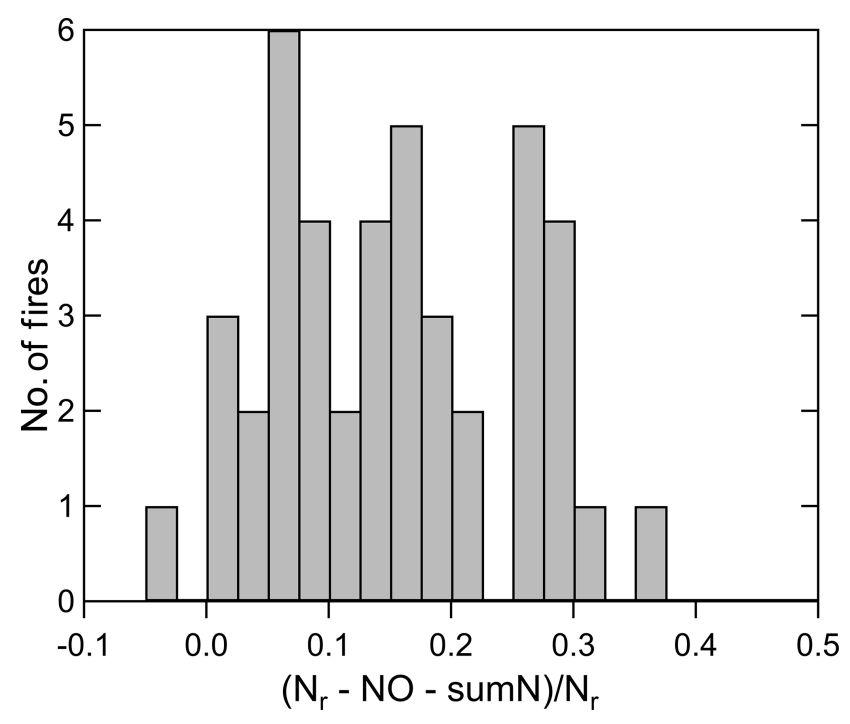

Figure 6. A histogram of the residual $\mathrm{N}$ for all the stack fires during the 2016 Fire Lab study for which there are FTIR, ACES, and PTRToF measurements $(n=43)$. The median is 0.143 , and the mean $( \pm \mathrm{SD})$ was $0.15( \pm 0.10)$.

ments of inorganic and NVOC species are listed in the Supplement as ratios to $\mathrm{N}_{\mathrm{r}}$ for each stack fire (Table S1). The summary of all the fire integrated $X_{i} / \mathrm{N}_{\mathrm{r}}$ fractions (where $X_{i}$ is the $\mathrm{N}_{\mathrm{r}}$ species or quantity) is given in Table 3 for all the fires for which we have a complete set of measurements (43 fires). In general, NO was the major species, followed by $\mathrm{NH}_{3}$, and the other inorganic $\mathrm{N}_{\mathrm{r}}$ species, $\mathrm{NO}_{2}, \mathrm{HNCO}$, $\mathrm{HONO}$, and $\mathrm{HCN}$ had individual contributions of $4.3 \%$ to $9.4 \%$. NVOC species were less than $5 \%$ of $\mathrm{N}_{\mathrm{r}}$ on average. The unaccounted-for $\mathrm{N}_{\mathrm{r}}$, defined as $\left(\mathrm{N}_{\mathrm{r}}-\mathrm{NO}-\right.$ sumN $) / \mathrm{N}_{\mathrm{r}}$ had a median value of $14.3 \%$ and a mean $( \pm$ SD) of 15 $( \pm 10) \%$. Overall, $85 \%$ of $\mathrm{N}_{\mathrm{r}}$ was accounted for by the gasphase measurements. The distribution of whole-fire $\mathrm{N}_{\mathrm{r}}$ residuals is plotted as a histogram in Fig. 6. We expect the residual $\mathrm{N}_{\mathrm{r}}$ was composed of either semi- or low-volatility compounds or particle-bound $\mathrm{N}_{\mathrm{r}}$ compounds, which we know are converted efficiently by the $\mathrm{N}_{\mathrm{r}}$ catalyst (Stockwell et al.,
2018) but not detected by the instruments included in this analysis. Along these lines, there is some indication that the residual has a systematic variation with whole-fire MCE, with higher residuals (up to $30 \%$ ) observed at lower MCEs and higher $\left(\mathrm{N}_{\mathrm{r}}-\mathrm{NO}\right) / \mathrm{N}_{\mathrm{r}}$ (see Fig. S3a, b), which would be consistent with higher EF for SVOC at low MCE (Jen et al., 2019) and particle $\mathrm{N}_{\mathrm{r}}$ having a higher contribution from $\mathrm{NO}_{3}^{-}$(May et al., 2014) and, perhaps, particle ammonium or reduced- $\mathrm{N}_{\mathrm{r}}$ compounds. In general, there is more particulate organic material emitted from fires at low MCE (Jen et al., 2019), so we would expect more particle $\mathrm{N}$ at low MCE to go along with that.

\subsection{Systematic dependences of $\mathrm{N}_{\mathrm{r}}$ composition on combustion processes}

The features noted in fires shown above, as well as the anticorrelation of MCE and $\left(\mathrm{N}_{\mathrm{r}}-\mathrm{NO}\right) / \mathrm{N}_{\mathrm{r}}$ lead to the question of whether there are systematic dependences in $\mathrm{N}_{\mathrm{r}}$-compound composition on fire stage that can be used to formally classify and/or potentially predict the relative emissions of $\mathrm{N}_{\mathrm{r}}$ compounds. MCE has been used as a rough indicator of the relative amounts of flaming and smoldering combustion in a fire, with high MCE ( 99\%) being "pure" flaming, low MCE ( $80 \%)$ being "pure smoldering," and an MCE of $\sim 0.9$ being roughly equal amounts of both (Sect. 2.1.1 in Akagi et al., 2011). It should be understood that "smoldering" in this framework is a lumped term that includes all nonflame processes such as pyrolysis, glowing, and distillation, which are the processes that produce gaseous fuel to support flaming (Yokelson et al., 1996). In addition, pure flaming is essentially the efficient oxidation of smoldering products before they enter the atmosphere. However, for MCE to predict flaming and smoldering $\mathrm{N}_{\mathrm{r}}$ species well, the variable fuel $\mathrm{N}$ must be considered. For instance, $\mathrm{NO}_{x}$ is clearly produced by flaming based on its temporal profile, but fire-integrated $\mathrm{EF}_{\mathrm{NO}_{x}}$ may not correlate with MCE due to variable fuel $\mathrm{N}$. In these cases, $\mathrm{EF}_{\mathrm{NO}_{x}} /$ fuel $\mathrm{N}$ or $\Delta \mathrm{NH}_{3} / \Delta \mathrm{NO}_{x}$ may still correlate (or anticorrelate) well with MCE (e.g., Fig. 4 in Burling et al., 2010, or Yokelson et al., 1996). Finally, the flame chemistry involving $\mathrm{NH}_{3}, \mathrm{HNCO}$, and $\mathrm{HCN}$ both produces and destroys NO in a fashion that does not conserve $\mathrm{N}_{\mathrm{r}}$. This chemistry is explored in Fig. 7, in which $\mathrm{NO}_{x}, \mathrm{NH}_{3}$, $\mathrm{HNCO}, \mathrm{HCN}, \mathrm{HONO}$, and $\mathrm{CH}_{3} \mathrm{CN}$ ratios to $\mathrm{N}_{\mathrm{r}}$ are plotted vs. real-time MCE for Fire 047 as a typical example for fires that have a substantial range of MCEs (e.g., from 0.8 to above 0.98). The relationship between $\mathrm{NH}_{3} / \mathrm{N}_{\mathrm{r}}$ and MCE confirms that $\mathrm{NH}_{3}$ is primarily a smoldering emission, and $\mathrm{NO}_{x} / \mathrm{N}_{\mathrm{r}}$ increases with increasing MCE in a nonlinear fashion that confirms it is primarily a flaming compound. Such a nonlinear dependence has also been seen for other flamingrelated quantities such as elemental carbon/TC or $\mathrm{EF}_{\mathrm{HCl}}$ (Christian et al., 2003; Stockwell et al., 2014). Most importantly, the variations in $\mathrm{HNCO} / \mathrm{N}_{\mathrm{r}}, \mathrm{HCN} / \mathrm{N}_{\mathrm{r}}, \mathrm{HONO} / \mathrm{N}_{\mathrm{r}}$, and $\mathrm{CH}_{3} \mathrm{CN} / \mathrm{N}_{\mathrm{r}}$ versus $\mathrm{MCE}$ do not arise dominantly from 


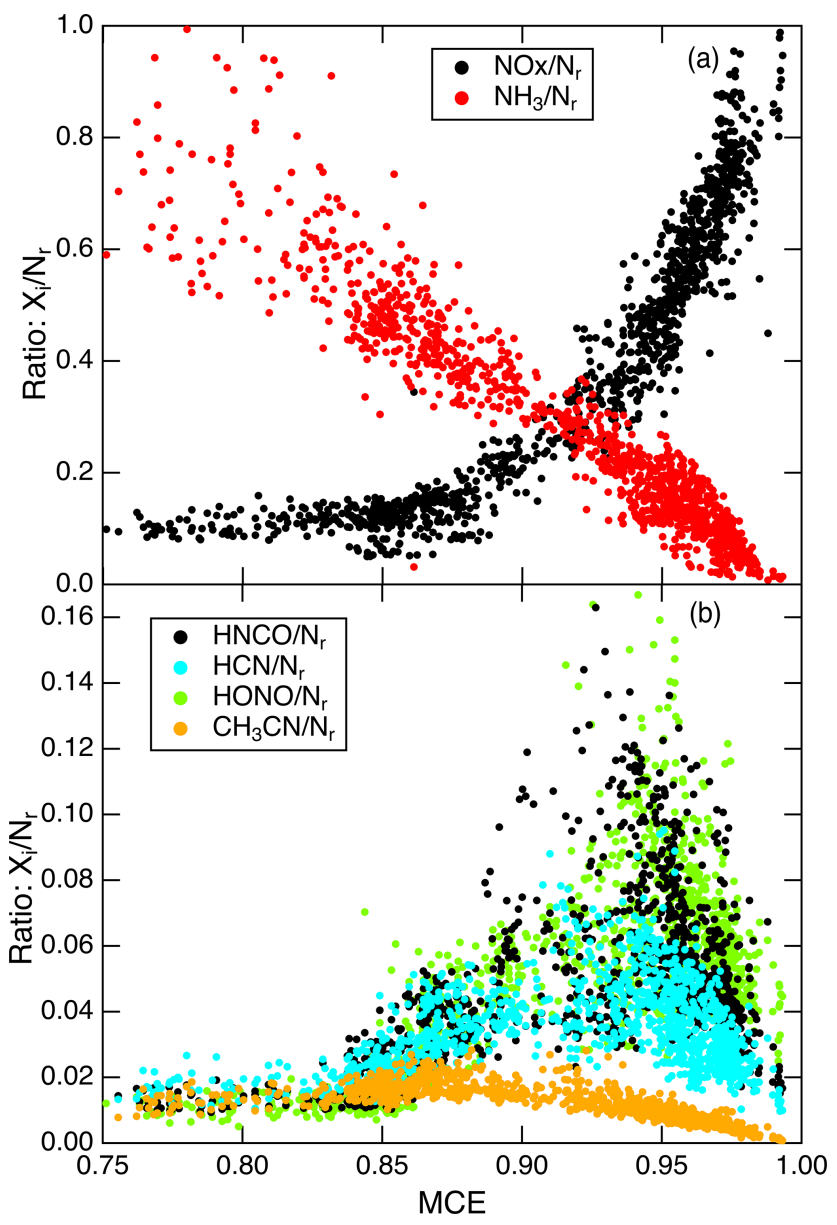

Figure 7. (a) The relationships between $\mathrm{NO}_{x} / \mathrm{N}_{\mathrm{r}}$ and $\mathrm{NH}_{3} / \mathrm{N}_{\mathrm{r}}$ vs. MCE and (b) the $\mathrm{HNCO} / \mathrm{N}_{\mathrm{r}}, \mathrm{HCN} / \mathrm{N}_{\mathrm{r}}, \mathrm{HONO} / \mathrm{N}_{\mathrm{r}}$, and $\mathrm{CH}_{3} \mathrm{CN} / \mathrm{N}_{\mathrm{r}}$ vs. MCE for Fire 047.

either regime, as these are species that are likely produced by multiple pathways (e.g., "incomplete flaming", pyrolysis, or possibly glowing). By incomplete flame chemistry we mean the production of incompletely oxidized products in flames such as the complex system of reactions shown in Fig. 1. These reactions involving $\mathrm{HNCO}, \mathrm{HCN}$, and $\mathrm{NH}_{3}$ both produce and destroy $\mathrm{NO}$, while $\mathrm{HONO}$ is produced from reactions of $\mathrm{NO}$ and $\mathrm{NO}_{2}$ that are faster at slightly lower temperatures, for example the three-body association reaction of NO with OH radical (Manion et al., 2015). Variable turbulence in the turbulent diffusion flames that are characteristic of open BB likely contributes to varying temperatures and, therefore, varying amounts of incomplete oxidation of the fuel N (Shaddix et al., 1994).

\subsection{The PMF analysis of coniferous fuels}

The complexity of the dependence of $\mathrm{N}_{\mathrm{r}}$ speciation on combustion chemistry suggests that MCE is an insufficient model to use for applying lab results to real-world fire emissions

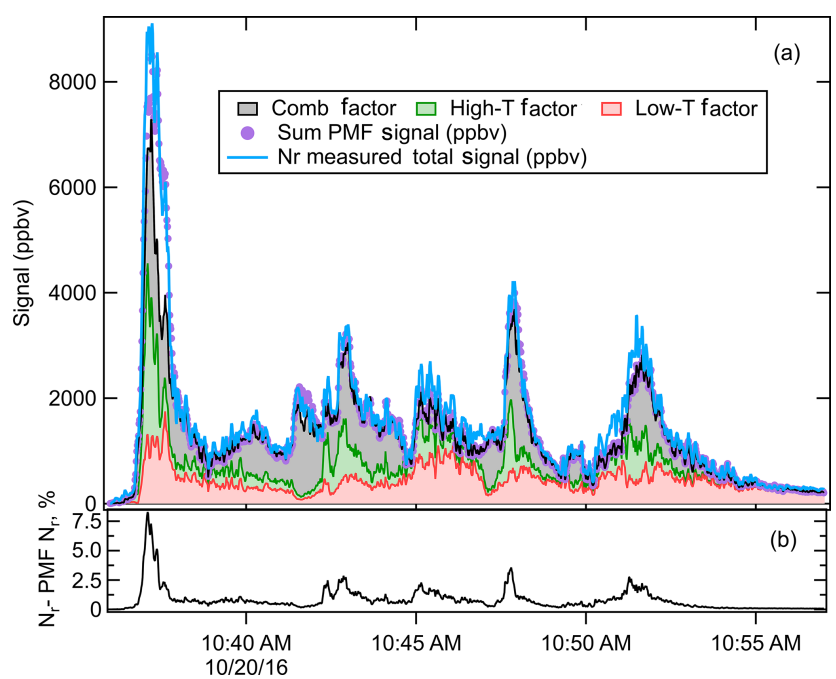

Figure 8. (a) The measured $\mathrm{N}_{\mathrm{r}}$ signal for Fire 063 (lodgepole pine) (blue line), the sum of the signal reconstructed by the PMF (purple points), and the three PMF factors - combustion (grey), high temperature (green), and low temperature (red) - plotted in a stacked fashion (i.e., added on top of one another). (b) The "residual" of the PMF fit consisting of the measured $\mathrm{N}_{\mathrm{r}}$ signal minus the $\mathrm{N}_{\mathrm{r}}$ signal reconstructed by the PMF, as a percentage of the $\mathrm{N}_{\mathrm{r}}$ signal.

(Stockwell et al., 2016a; Yokelson et al., 2013b). Accordingly, we employed the positive matrix factorization (PMF) method (see Methodology section) that has been used by a number of groups to probe the sources contributing to complex mixtures (see for example Ulbrich et al., 2009; Sekimoto et al., 2018). Our PMF results showed several general features, irrespective of the inclusion or exclusion of $\mathrm{CO}_{2}, \mathrm{CO}$, and $\mathrm{N}_{\mathrm{r}}$. The emissions were best fit by three factors (with approximate descriptive names justified below and prime species): (1) a combustion (flaming) factor (abbreviated Comb-N), (2) a high-temperature pyrolysis factor (HT$\mathrm{N}$ ), and (3) a low-temperature pyrolysis factor (LT-N). We use these terms in part to harmonize our discussion with the VOC results discussed by Sekimoto et al. (2018). An example time series for the PMF analysis of a coniferous fuel with just the $N_{r}$ species included is shown in Fig. 8 for a realistic mix of lodgepole pine (Fire 063). In this case, several different $F_{\text {peak }}$ values were tried $(-1,0,+1)$ and runs with 100 different seeds (initial factor profiles) were performed. The results of those analyses (Fig. S4) show that a three-factor PMF result is robust. A PMF analysis was performed on the consolidated time series of all coniferous fuels fit using just the $\mathrm{N}_{\mathrm{r}}$ species, as shown in Fig. S5. In this case $F_{\text {peak }}=0$ was used, and the $Q / Q_{\text {expected }}$ showed an inflection for the three-factor solution at a value of 5.3. The three factors successfully describe the majority of the $\mathrm{N}_{\mathrm{r}}$ emissions where the difference between the measured and calculated mass is on average $5.1 \%$ for coniferous fuels and $4.6 \%$ for chaparrals as indicated in Table 4 . 
Table 4. Residuals of the PMF analyses by fuel, as percent of total signal.

\begin{tabular}{|c|c|c|c|c|}
\hline Fuel & Total number & Component & Fire number & Residual (\%), Avg (SD) \\
\hline \multirow[t]{3}{*}{ Ponderosa pine } & 9 & Realistic (mix) & Fire $37,59,72$ & $3.8( \pm 1.4)$ \\
\hline & & Canopy (pure) & Fire 39 & \\
\hline & & Litter (pure) & Fire 38 & \\
\hline \multirow[t]{3}{*}{ Lodgepole pine } & 5 & Realistic & Fire $07^{\mathrm{a}}, 58,63$ & $5.1( \pm 3.1)$ \\
\hline & & Canopy & Fire 40 & \\
\hline & & Litter & Fire 41 & \\
\hline \multirow[t]{3}{*}{ Douglas fir } & 4 & Realistic & Fire $14^{\mathrm{a}}, 57$ & $6.8( \pm 3.1)$ \\
\hline & & Canopy & Fire 18 & \\
\hline & & Litter & Fire $43^{\mathrm{a}}$ & \\
\hline \multirow[t]{3}{*}{ Subalpine fir } & 5 & Realistic & Fire 47,67 & $6.6( \pm 2.3)$ \\
\hline & & Canopy & Fire 15,23 & \\
\hline & & Litter & Fire $51^{\mathrm{a}}$ & \\
\hline \multirow[t]{2}{*}{ Engelmann spruce } & 2 & Realistic & Fire $08^{\mathrm{a}}$ & $3.1( \pm 1.9)$ \\
\hline & & Canopy & Fire 25 & \\
\hline Chamise (San Dimas, CA) & 2 & Canopy & Fire 24,29 & $4.4( \pm 2.7)$ \\
\hline Chamise (North Mountain, CA.) & 2 & Canopy & Fire 27,32 & $4.2( \pm 1.0)$ \\
\hline Manzanita (San Dimas, CA) & 2 & Canopy & Fire 30,33 & $4.8( \pm 2.1)$ \\
\hline Manzanita (North Mountain, CA.)) & 2 & Canopy & Fire 28 & 5.1 \\
\hline
\end{tabular}

Several metrics of the PMF analysis quantify how the compounds or compound classes contribute to each factor. The "loadings" of the three different factors, i.e., the contribution of compounds to each factor, for coniferous fuels are shown in Fig. 9a, and the distribution of a given compound or compound class amongst the three factors is shown in Fig. 9b as normalized fraction. Normalized fraction is equal to the PMF-determined contribution of a compound to a factor, divided by the sum of the contribution of the compound to all three factors. The Comb- $\mathrm{N}$ factor contained $\mathrm{NO}, \mathrm{NO}_{2}$, and HONO; the HT-N factor had mostly HCN, HNCO, and nitriles, with contributions from $\mathrm{NO}_{2}$ and nitro compounds; and the LT-N factor contained $\mathrm{NH}_{3}$, amines, amides, and heterocyclics. Within the Comb-N factor there is some evidence that the relative amounts of $\mathrm{HONO}$ and $\mathrm{NO}_{x}$ depend on fuel moisture. For example, the ratio $\mathrm{HONO} / \mathrm{NO}_{x}$ for whole fires shows some correlation with needle moisture in coniferous fires that were canopy fuels (foliage and small woody biomass), as shown in Fig. S6. This may be due to flame processes that interconvert $\mathrm{NO}_{x}$ and $\mathrm{HONO}$ in the presence of water vapor or $\mathrm{OH}$ (see Fig. 1).

Literature values from studies where flame temperature was measured are typically in the range of $1100-1200{ }^{\circ} \mathrm{C}$ (Taylor et al., 2004; Wotton et al., 2012), so we would assume that would constitute the upper range of our Comb-N factor. The radical chemistry involving $\mathrm{HCN}, \mathrm{HNCO}$, and $\mathrm{NH}_{3}$ starts to shut down below about $800-900^{\circ} \mathrm{C}$, according to the modeling of Glarborg et al. (2018), so we set $800^{\circ} \mathrm{C}$ as a lower limit for the Comb-N factor. The HT-N factor species are known to be produced by the intense pyrolysis of fuel $\mathrm{N}_{\mathrm{r}}$ compounds (Hansson et al., 2004; Liu et al., 2018; Ren et al., 2010), which for these compounds becomes important at temperatures around $500-600^{\circ} \mathrm{C}$. Accordingly, we estimate the temperature range for the HT-N factor at $500-800^{\circ} \mathrm{C}$. The remaining LT-N factor results from mild pyrolysis and pertains to fire conditions of roughly $500{ }^{\circ} \mathrm{C}$ and below, and it was dominated by $\mathrm{NH}_{3}$, amines, amides, and some of the more complex organics (Koss et al., 2018). The names and temperature ranges are approximate and likely include processes that occur inside flames as part of the flame proper, as turbulent diffusive flames are highly variable in space and time.

\subsection{The comparison of N-PMF factors to other fire parameters and VOC emission factors}

It is useful to explore the correlation of N-PMF factors with other fire indicators to determine relationships for parameterizing $\mathrm{N}_{\mathrm{r}}$ emissions together with carbon and VOC emissions, in order to simplify how emissions might be parameterized in models. The Comb-N factor for coniferous fuels, which consisted of $\mathrm{NO}_{x}$ and $\mathrm{HONO}$, would be expected to correlate with $\mathrm{CO}_{2}$ but not as well with MCE since the latter includes an indicator of incomplete combustion. The time series of Comb-N along with $\mathrm{CO}_{2}$ and with MCE for Fire 037 (ponderosa pine) are plotted in Fig. 10. As expected they show an excellent correlation of Comb-N with $\mathrm{CO}_{2}\left(R^{2}=0.942\right)$, 


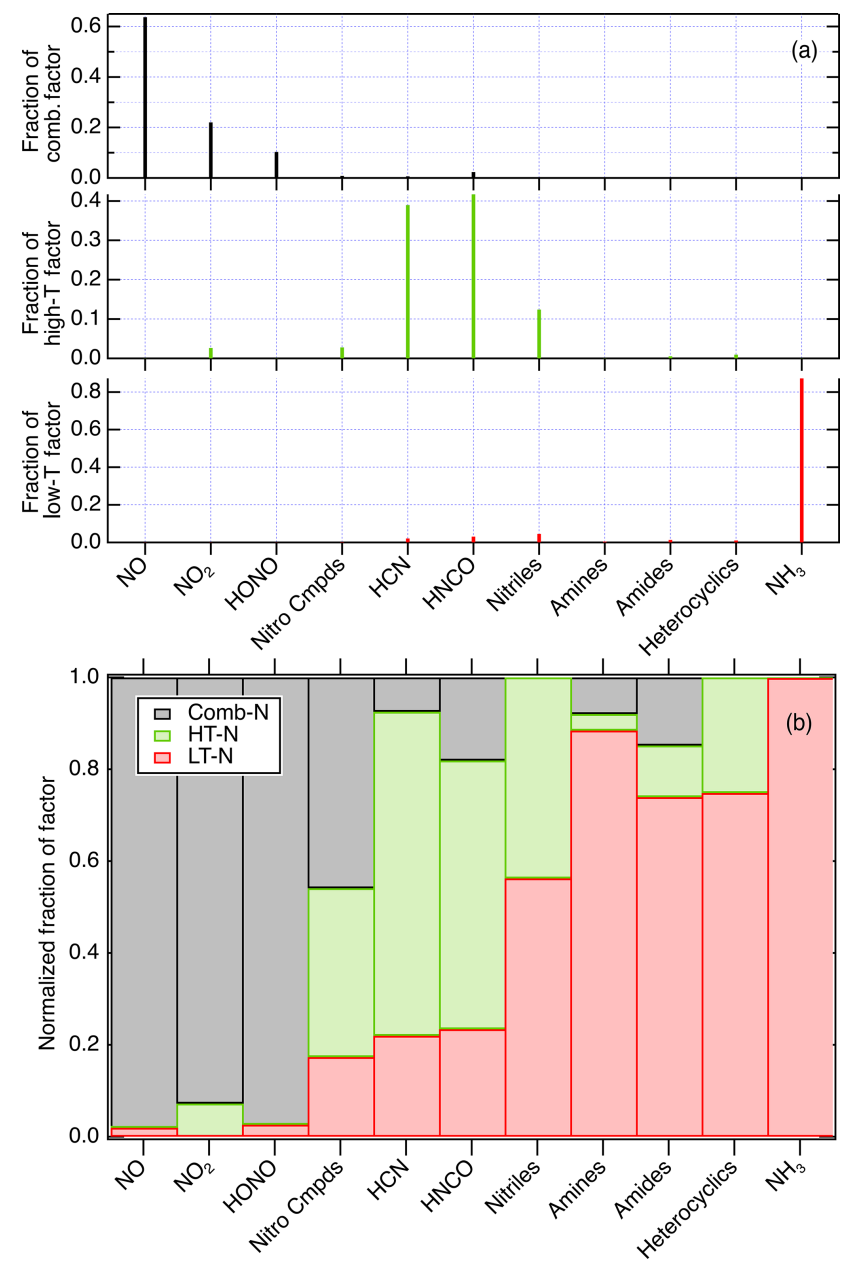

Figure 9. (a) The contributions of nitrogen species to the factors that simulate the emissions from coniferous fuels shown in Fig. S2 and (b) the fraction of each compound or class found in each factor.

since all the species are flaming compounds, but nonlinear correlation of Comb-N with MCE $\left(R^{2}=0.363\right)$, since the latter factors in a smoldering compound (CO), similar to the $\mathrm{NO}_{x} / \mathrm{N}_{\mathrm{r}}$ vs. MCE plot for Fire 047 in Fig. 7. The excellent correlation of Comb-N with $\mathrm{CO}_{2}$ is a broadly applicable result; the $R^{2}$ parameters for all the fires shown in Fig. S5 had an average of 0.898 and ranged from 0.806 to 0.966 . As a consequence, we can conclude that $\mathrm{CO}_{2}$ would be the best tracer for Comb-N in many western US ecosystems where conifers predominate, provided ambient $\mathrm{CO}_{2}$ backgrounds can be properly accounted for as described by Yokelson et al. (2013a).

Our Comb-N factor did not correspond to the hightemperature VOC factor (HT-VOC) found by Sekimoto et al. (2018) in their pyrolysis study, because our broader study includes flaming combustion, which produces $\mathrm{NO}_{x}$ and HONO, and almost none of the compounds classified as VOCs survive flaming conditions. However, the HT-N and HT-VOC factors are both linked to pyrolysis and were well correlated for many fires. An example of this is shown in Fig. 11 for Fire 037, a sample that was broadly representative of ponderosa pine (i.e., canopy and litter). This result can be rationalized by the fact that while HT-VOC factors have large contributions from many more compounds than the $\mathrm{N}$ compounds measured here, they also have large contributions $(>85 \%)$ from HCN, HNCO, and HONO (in other words $>85 \%$ of $\mathrm{HCN}, \mathrm{HNCO}$, and $\mathrm{HONO}$ are found in the HT-VOC factor). Since the HT-N factors are also heavily weighted by $\mathrm{HCN}$ and $\mathrm{HNCO}$, it is reassuring that both of these PMF analyses have independently identified these species as important contributors to the HT fire regime. The $R^{2}$ correlation coefficients between the HT-N and HT-VOC factors for the coniferous fires shown in Fig. S5 averaged 0.866 and ranged from 0.419 to 0.959 . As a consequence of this correlation, we can conclude that $\mathrm{HCN}$ is the best marker for the HT-N and HT-VOC factors in most western US wildfires, since $\mathrm{HCN}$ is essentially inert on the timescales of fire plumes (Li et al., 2000). It should be noted that other nitriles, particularly acetonitrile, also show up in the HT-N factor, and acetonitrile has also been used as a tracer of biomass combustion. However, it has been shown that this acetonitrile signal can be obscured in urban or industrial areas by solvent usage or can be quite small in woodstove emissions due to low $\mathrm{N}$ in the fuel (Coggon et al., 2016).

The correlations of LT-N and LT-VOC factors were not particularly high for most of the coniferous fires shown in Fig. S5. The average $R^{2}$ was 0.427 with a range of between 0.072 and 0.827 . The reasons for this lack of correlation are not clear, as $\mathrm{NH}_{3}$, amines, and amides appear predominantly in both LT factors, and the absolute concentrations of $\mathrm{NH}_{3}$ are usually quite high in these fires relative to VOCs (Sekimoto et al., 2018). However, the LT-VOC factor includes many more compounds with a variety of functional groups not found in the LT-N factor, so it appears that the VOC and $\mathrm{N}$ compounds have sufficiently different pyrolysis chemistry that the LT factors do not show much correlation. We conclude that $\mathrm{NH}_{3}$ (and particle $\mathrm{NH}_{4}^{+}$) will be the best marker for the LT-N factor in western US coniferous wildfires, but the LT-VOC chemistry might not be captured reliably by this marker.

\subsection{PMF analysis of chaparral fuels}

Chaparral is an important ecosystem of concern in wildfires that occur in central and southern California and other areas of the southwestern US. The emissions from burning chaparral fuels (manzanita and chamise) collected at two sites in California were also analyzed as a group and yielded three separate factors in a fashion similar to the coniferous fuels (see Fig. S7 for the PMF timeline). As with the coniferous fuels, there was essentially no change in the three-factor solution with $F_{\text {peak }}$, so $F_{\text {peak }}=0$ was used, and the $Q / Q_{\text {exp }}$ was 3.8. The chaparral factors had slightly different composition (Fig. S8); the combustion factor was mostly NO, with small 

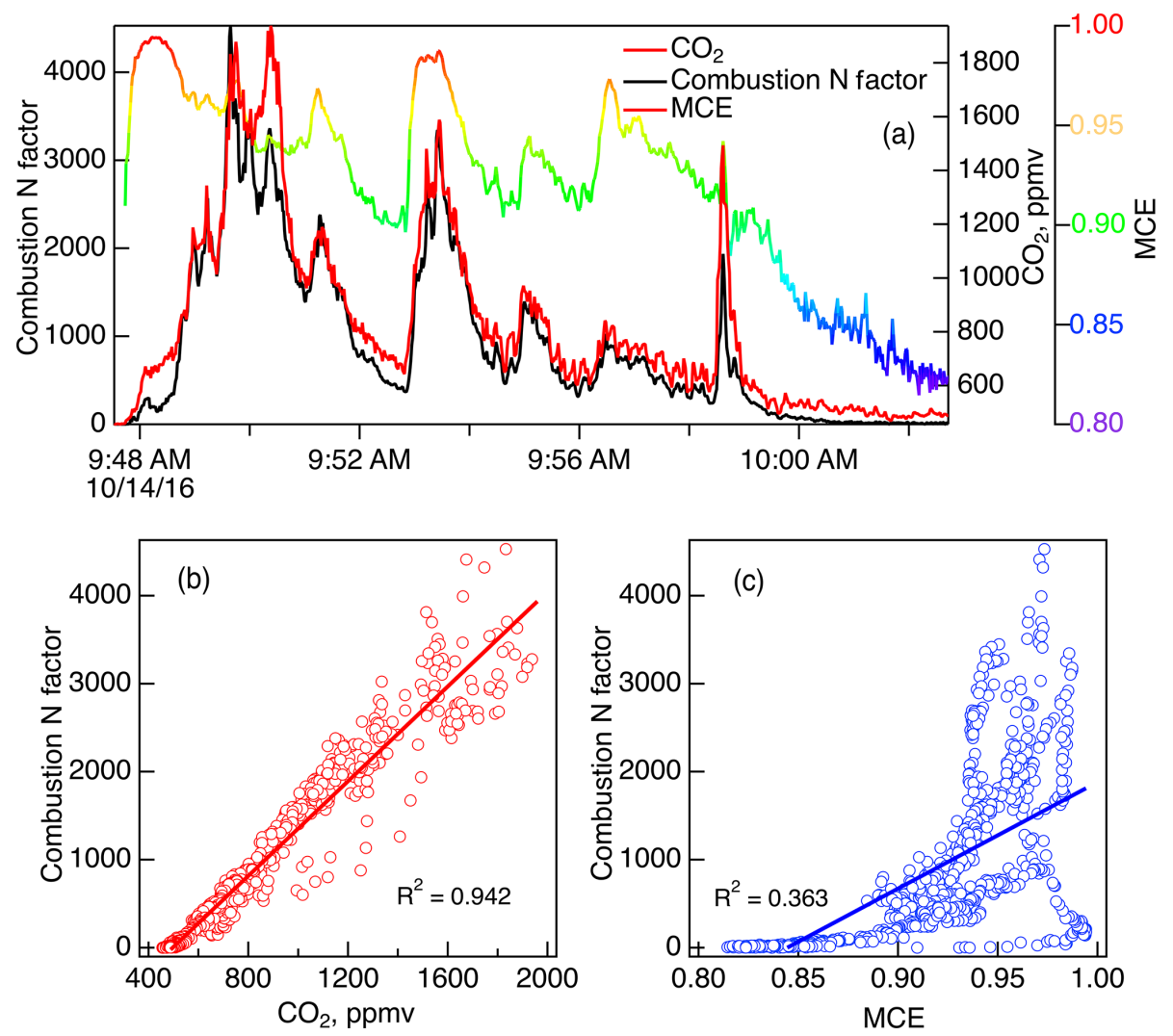

Figure 10. Comparisons of the N-PMF combustion factor (Comb-N) with (a) $\mathrm{CO}_{2}$ and $\mathrm{MCE}$ for Fire 037 (ponderosa pine). Panel (b) shows the scatter plot of the Comb-N factor versus $\mathrm{CO}_{2}$, and panel (c) shows the scatter plot of Comb-N factor versus MCE.

amounts of $\mathrm{HNCO}, \mathrm{HONO}$, and $\mathrm{NH}_{3}$; the high-temperature factor was dominated by $\mathrm{NO}_{2}$ and included $\mathrm{HONO}, \mathrm{HCN}$, and $\mathrm{HNCO}$; and the low-temperature factor was mostly $\mathrm{NH}_{3}$ with a slight amount of NO contributing. The NVOC species were found in both the medium- and low-temperature factors.

There was less similarity between the Comb-N factor and $\mathrm{CO}_{2}$ emissions for chaparral fuels compared to those found for coniferous fuels, with an average correlation coefficient $\left(R^{2}\right)$ of 0.689 , with a range from 0.244 and 0.950 . As a result, there may not be a simple conserved tracer for the combustion factor of these fuel types; however total odd nitrogen $\left(\mathrm{NO}_{y}\right)$ which is $\mathrm{NO}_{x}$ and all the compounds that are produced from $\mathrm{NO}_{x}$ in the troposphere, may be useful as it is a reasonably conserved tracer in the absence of wet or dry deposition of particles. Correlation coefficients between the HT-N and HT-VOC factors were on average $R^{2}=0.551$, with a range $0.047-0.911$. The correlations between LT-N and LT-VOC factors were in the same range for chaparral fuels as for coniferous, with average $R^{2}=0.447$, range 0.028 0.827 .

There were some fuels that do not sustain flaming combustion well, specifically duff, Yak dung, and Indonesian peat. These fires exhibited little or no NO emission commensurate with minimal flaming combustion. Instead the emissions were mostly the pyrolysis products $\mathrm{NH}_{3},\left(0.22-0.53 \mathrm{~N}_{\mathrm{r}}\right.$ fraction), and $\mathrm{HCN}$ (up to $0.32 \mathrm{~N}_{\mathrm{r}}$ fraction for peat). It was also apparent that these fires also had unaccounted-for $\mathrm{N}_{\mathrm{r}}$, close to or just over 0.30 (Table S1). The distribution of $\mathrm{N}_{\mathrm{r}}$ compounds in the one peat fire that we measured (Fire 055) is in line with those reported for fires measured in situ, which showed relatively high EFs for $\mathrm{HCN}$ and $\mathrm{NH}_{3}$ (Stockwell et al., 2016b, 2015).

\subsection{Application to real-world fires}

The application of our $\mathrm{N}_{\mathrm{r}}$ emissions results to real-world fires will depend somewhat on the nature of the information available on a particular fire or fire complex. As a good starting point, or in the absence of detailed $\mathrm{N}$ and $\mathrm{C}$ analyses of fuels, a $\mathrm{N}_{\mathrm{r}} / \mathrm{C}$ ratio of $0.37 \%$ appears to capture most of the fires studied in this work. The $\mathrm{N}_{\mathrm{r}}$ could be apportioned according to the results summarized in Table 3. Adjustments to those fractions can be made by scaling slightly by average MCE, with the knowledge that intermediate species (HT-N pyrolysis species) such as HCN and HNCO do not scale in the simple manner that $\mathrm{NH}_{3}$ and $\mathrm{NO}_{x}$ do. If measurements of marker compounds are available then $\mathrm{CO}_{2}, \mathrm{HCN}$, and the sum $\mathrm{NH}_{3}+\mathrm{NH}_{4}^{+}$can be used for the combustion, 

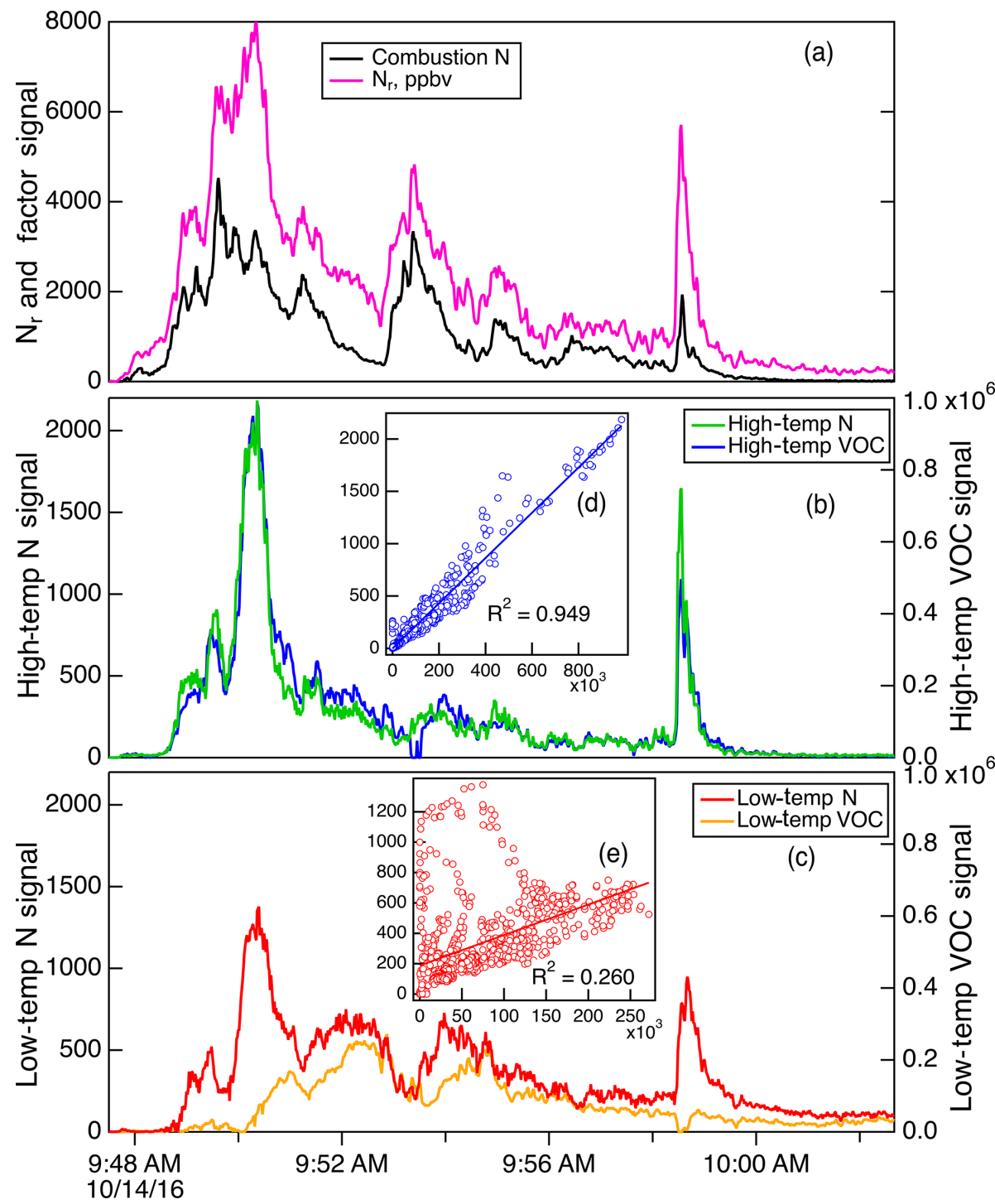

Figure 11. Details of the PMF factors for Fire 037 (ponderosa pine). Panel (a) shows the total $\mathrm{N}_{\mathrm{r}}$ signal (magenta) and the Comb-N factor (black); panel (b) shows the HT-N factor (green) and HT- VOC factor (blue), and panel (c) shows the LT-N factor (red) and LT-VOC factor (orange). The insets (d) and (e) show the correlation of the two HT factors and the correlation between the two LT factors, respectively.

high-temperature pyrolysis, and low-temperature pyrolysis factors, respectively.

\section{Conclusions}

Seventy-five stack fire experiments were conducted during the FIREX Fire Lab experiments in Fall 2016. A range of fuels characteristic of the western US was burned under conditions and in mixtures meant to represent authentic wildfire conditions, as closely as is possible in the laboratory. Total reactive nitrogen $\left(\mathrm{N}_{\mathrm{r}}\right.$ : all $\mathrm{N}$-containing compounds except $\mathrm{N}_{2}$ and $\mathrm{N}_{2} \mathrm{O}$ ) was measured along with a suite of $\mathrm{N}$-containing compounds in order to obtain a budget for $\mathrm{N}_{\mathrm{r}}$ emissions and to examine relationships between fuels, combustion conditions, and emissions chemistry.

Natural convection wildfires do not burn hot enough to produce $\mathrm{NO}_{x}$ from $\mathrm{N}_{2}$ and $\mathrm{O}_{2}$, so all $\mathrm{N}_{\mathrm{r}}$ emissions come from the fuel N. Almost all of the fires representative of North American ecosystems had emissions that clustered around a $\mathrm{N}_{\mathrm{r}} / \mathrm{C}$ ratio of $0.37 \%$, which can serve as a starting point for scaling emissions from these ecosystems. Comparing total $\mathrm{N}_{\mathrm{r}}$ and total carbon emissions with the N/C ratios of both the original fuel and remaining ash allowed us to estimate that an average of $68 \%( \pm 14 \%)$ of the fuel nitrogen ends up as $\mathrm{N}_{2}$ and $\mathrm{N}_{2} \mathrm{O}$. This loss of nitrogen can be used to estimate how much fuel nitrogen ends up as $\mathrm{N}_{\mathrm{r}}$. Of the remaining $\mathrm{N}$ emitted as $\mathrm{N}_{\mathrm{r}}$, approximately $85 \%( \pm 10 \%)$ was accounted 
for by individually measured gas-phase species, while the rest was most likely particle-bound $\mathrm{NH}_{4}^{+}$and $\mathrm{NO}_{3}^{-}$, with a smaller contribution from low-volatility species or other species such as cyanogen (Lobert and Warnatz, 1993), that were not quantified by the instruments for individual measurements we used in this study. The speciation and modeling of $\mathrm{N}_{\mathrm{r}}$ we present promotes accurate modeling of fire plume chemistry since the photochemistry of many fire plumes is $\mathrm{NO}_{x}$-limited, and $\mathrm{NH}_{3}$ is an important contributor to particle chemistry.

The individual $\mathrm{N}_{\mathrm{r}}$ species composition normalized to total $\mathrm{N}_{\mathrm{r}}$, to account for fuel $\mathrm{N}$ variability, correlated monotonically with flaming versus vs. smoldering combustion as indicated by modified combustion efficiency (MCE) for some species (e.g., $\mathrm{NH}_{3}, \mathrm{NO}_{x}$ ). Other species, such as $\mathrm{HCN}$ and HNCO, peaked at intermediate MCE values. Positive matrix factorization (PMF) showed that all the measured $\mathrm{N}_{\mathrm{r}}$ emissions from the main two categories of fuels, conifers, and chaparral, grouped into three mixtures (factors), roughly attributed to temperature: combustion $\left(\mathrm{NO}_{x}, \mathrm{HONO}\right)$, high temperature ( $\mathrm{HNCO}, \mathrm{HCN}$, nitriles), and low-temperature $\left(\mathrm{NH}_{3}\right.$, amines, amides). Chemical kinetic and pyrolysis considerations set the temperature ranges for these regimes at approximately $800-1200,500-800$, and $<500^{\circ} \mathrm{C}$, respectively.

This paper connects mechanistic aspects of $\mathrm{N}$ combustion chemistry to the budget of $\mathrm{N}_{\mathrm{r}}$ emissions from biomass burning. The emission composition measurements detailed here give useful information concerning what the initial conditions will be in actual fire plumes. These results suggest that for coniferous fuels characteristic of the western US, $\mathrm{CO}_{2}$ is the best marker for flaming combustion, $\mathrm{HCN}$ is the best marker for high-temperature pyrolysis processes, and $\mathrm{NH}_{3} / \mathrm{NH}_{4}^{+}$is the best marker for low-temperature pyrolysis processes. The HT-N and HT-VOC pyrolysis factors showed a high degree of correlation especially for coniferous fuels, which can simplify how these different classes of emissions can be estimated. Results from less comprehensive field experiments can be combined with this emissions information to improve the representation of $\mathrm{N}_{\mathrm{r}}$ chemistry in the modeling frameworks needed to predict fire plume chemistry and impacts.

Data availability. The FIREX Fire Lab 2016 data are available at https://esrl.noaa.gov/csd/groups/csd7/measurements/2016firex/ FireLab/DataDownload/ (NOAA, 2020b). The descriptions of the measurements can be found at https://esrl.noaa.gov/csd/groups/ csd7/measurements/2016firex/FireLab/dataidtable.html (last access: 1 June 2020). The complete ash analyses are available on request.

Supplement. The supplement related to this article is available online at: https://doi.org/10.5194/acp-20-8807-2020-supplement.
Author contributions. JMR, RJY, CW, and JdG designed the research. The measurements were conducted by JMR, CES, CW, RJY, JdG, YL, VS, ARK, KS, MMC, BY, KJZ, SSB, CS, and SHD. All authors contributed to the discussion and interpretation of the results and writing the paper.

Competing interests. Joost de Gouw worked as a consultant for Aerodyne Research during part of the preparation phase of this paper.

Disclaimer. Any mention of brand names or manufacturers is for information purposes only and does not constitute an endorsement.

Acknowledgements. Abigail R. Koss acknowledges funding from the NSF Graduate Fellowship Program. Kanako Sekimoto acknowledges funding from the Postdoctoral Fellowships for Research Abroad from Japan Society for the Promotion of Science (JSPS) and a Grant-in-Aid for Young Scientists (B) (15K16117) from the Ministry of Education, Culture, Sports, Science and Technology of Japan. Robert J. Yokelson and Vanessa Selimovic were supported by NOAA-CPO grant no. NA16OAR4310100. Joost de Gouw was supported by the NSF AGS grant no. 1748266 under a subcontract to the University of Montana during the analysis phase of this work. We thank the USFS Missoula Fire Sciences Laboratory for their help in conducting these experiments, especially Shawn Urbanski and Thomas Dzomba. This work was also supported by NOAA's Climate Research and Health of the Atmosphere initiatives.

Financial support. This research has been supported by the Japanese Society for the promotion of Science (grant no. 15K16117), the NOAA Climate Program Office (grant no. NA16OAR4310100), and the National Science Foundation (grant no. NSF AGS1748266).

Review statement. This paper was edited by Andreas Hofzumahaus and reviewed by two anonymous referees.

\section{References}

Abatzoglou, J. T. and Williams, A. P.: Impact of anthropogenic climate change on wildfire across western US forests, P. Natl. Acad. Sci. USA, 113, 11770-11775, 2016.

Akagi, S. K., Yokelson, R. J., Wiedinmyer, C., Alvarado, M. J., Reid, J. S., Karl, T., Crounse, J. D., and Wennberg, P. O.: Emission factors for open and domestic biomass burning for use in atmospheric models, Atmos. Chem. Phys., 11, 4039-4072, https://doi.org/10.5194/acp-11-4039-2011, 2011.

Akagi, S. K., Craven, J. S., Taylor, J. W., McMeeking, G. R., Yokelson, R. J., Burling, I. R., Urbanski, S. P., Wold, C. E., Seinfeld, J. H., Coe, H., Alvarado, M. J., and Weise, D. R.: Evolution of trace gases and particles emitted by a chaparral fire in California, At- 
mos. Chem. Phys., 12, 1397-1421, https://doi.org/10.5194/acp12-1397-2012, 2012.

Alvarado, M. J., Logan, J. A., Mao, J., Apel, E., Riemer, D., Blake, D., Cohen, R. C., Min, K.-E., Perring, A. E., Browne, E. C., Wooldridge, P. J., Diskin, G. S., Sachse, G. W., Fuelberg, H., Sessions, W. R., Harrigan, D. L., Huey, G., Liao, J., Case-Hanks, A., Jimenez, J. L., Cubison, M. J., Vay, S. A., Weinheimer, A. J., Knapp, D. J., Montzka, D. D., Flocke, F. M., Pollack, I. B., Wennberg, P. O., Kurten, A., Crounse, J., Clair, J. M. St., Wisthaler, A., Mikoviny, T., Yantosca, R. M., Carouge, C. C., and Le Sager, P.: Nitrogen oxides and PAN in plumes from boreal fires during ARCTAS-B and their impact on ozone: an integrated analysis of aircraft and satellite observations, Atmos. Chem. Phys., 10, 9739-9760, https://doi.org/10.5194/acp10-9739-2010, 2010.

Andreae, M. O.: Emission of trace gases and aerosols from biomass burning - an updated assessment, Atmos. Chem. Phys., 19, 8523-8546, https://doi.org/10.5194/acp-19-8523-2019, 2019.

Andreae, M. O. and Merlet, P.: Emission of trace gases and aerosols from biomass burning, Global Biogeochem. Cycles, 15, 955966, 2001

Benedict, K. B., Prenni, A. J., Carrico, C. M., Sullivan, A. P., Schichtel, B. A., and Collett Jr., J. L.: Enhanced concentrations of reactive nitrogen species in wildfire smoke, Atmos Environ., 148, 8-15, 2017.

Burling, I. R., Yokelson, R. J., Griffith, D. W. T., Johnson, T. J., Veres, P., Roberts, J. M., Warneke, C., Urbanski, S. P., Reardon, J., Weise, D. R., Hao, W. M., and de Gouw, J.: Laboratory measurements of trace gas emissions from biomass burning of fuel types from the southeastern and southwestern United States, Atmos. Chem. Phys., 10, 11115-11130, https://doi.org/10.5194/acp-10-11115-2010, 2010.

Christian, T. J., Kleiss, B., Yokelson, R. J., Holzinger, R., Crutzen, P. J., W. M., H., Saharjo, B. H., and Ward, D. E.: Comprehensive laboratory measurements of biomass-burning emissions: 1 . Emissions from Indonesian, African, and other fuels, J. Geophys. Res., 108, 4719, https://doi.org/10.1029/2003JD003704, 2003.

Coggon, M., Veres, P. R., Yuan, B., Koss, A. R., Warneke, C., Gilman, J. B., Lerner, B., Peischl, J., Aikin, K., Stockwell, C. E., Hatch, L. E., Ryerson, T. B., Roberts, J. M., Yokelson, R. J., and de Gouw, J.: Emissions of nitrogen-containing organic compounds from the burning of herbaceous and arboraceous biomass: fuel composition dependence and the variability of commonly used nitrile tracers, Geophys. Res. Lett., 43, 99039912, 2016.

Crutzen, P. J. and Andreae, M. O.: Biomass burning in the tropics: Impact on atmospheric chemistry and biogeochemical cycles, Science, 250, 1669-1678, 1990.

Gilman, J. B., Lerner, B. M., Kuster, W. C., Goldan, P. D., Warneke, C., Veres, P. R., Roberts, J. M., de Gouw, J. A., Burling, I. R., and Yokelson, R. J.: Biomass burning emissions and potential air quality impacts of volatile organic compounds and other trace gases from fuels common in the US, Atmos. Chem. Phys., 15, 13915-13938, https://doi.org/10.5194/acp-15-139152015, 2015.

Goode, J. G., Yokelson, R. J., Susott, R. A., and Ward, D. E.: Trace gas emissions from laboratory biomass fires measured by openpath Fourier transform infrared spectroscopy: Fires in grass and surface fuels J. Geophys. Res., 104, 21237-21245, 1999.
Glarborg, P., Miller, J. A., Ruscic, B., and Klippenstein, S. J.: Modeling nitrogen chemistry in combustion, Prog. Energy Comb. Sci., 67, 31-68, 2018.

Griffith, D. W. T., Mankin, W. G., Coffey, M. T., Ward, R. E., and Riebau, A.: FTIR remote sensing of biomass burning emissions of $\mathrm{CO}_{2}, \mathrm{CO}, \mathrm{CH}_{4}, \mathrm{CH}_{2} \mathrm{O}, \mathrm{NO}, \mathrm{NO}_{2}, \mathrm{NH}_{3}$, and $\mathrm{N}_{2} \mathrm{O}$, in: Global Biomass Burning: Atmospheric, Climatic, and Biospheric Implications, edited by: Levine, J. S., The MIT Press, Cambridge, MA, 1991.

Hansson, K.-M., Samuelsson, J., Tullin, C., and Amand, L.-E.: Formation of $\mathrm{HNCO}, \mathrm{HCN}$, and $\mathrm{NH}_{3}$ from the pyrolysis of bark and nitrogen-containing model compounds, Combust. Flame, 137, 265-277, 2004.

Hao, W. M., Scharffe, D. H., Lobert, J. M., and Crutzen, P. J.: Emissions of $\mathrm{N}_{2} \mathrm{O}$ from the burning of biomass in an experimental system, Geophys. Res. Lett., 18, 999-1002, 1991.

Hardy, J. E. and Knarr, J. J.: Technique for measuring the total concentration of gaseous fixed nirogen species, J. Air Pollut. Contr. Assoc., 32, 376-379, 1982.

Jayarathne, T., Stockwell, C. E., Bhave, P. V., Praveen, P. S., Rathnayake, C. M., Islam, Md. R., Panday, A. K., Adhikari, S., Maharjan, R., Goetz, J. D., DeCarlo, P. F., Saikawa, E., Yokelson, R. J., and Stone, E. A.: Nepal Ambient Monitoring and Source Testing Experiment (NAMaSTE): emissions of particulate matter from wood- and dung-fueled cooking fires, garbage and crop residue burning, brick kilns, and other sources, Atmos. Chem. Phys., 18, 2259-2286, https://doi.org/10.5194/acp18-2259-2018, 2018.

Jen, C. N., Hatch, L. E., Selimovic, V., Yokelson, R. J., Weber, R., Fernandez, A. E., Kreisberg, N. M., Barsanti, K. C., and Goldstein, A. H.: Speciated and total emission factors of particulate organics from burning western US wildland fuels and their dependence on combustion efficiency, Atmos. Chem. Phys., 19, 1013-1026, https://doi.org/10.5194/acp-19-1013-2019, 2019.

Kashihira, N., Makino, K., Kirita, K., and Watanabe, Y.: Chemiluminescent nitrogen detector-gas chromatotography and its application to measurement of atmospheric ammonia and amines, J. Chromatogr., 239, 617-624, 1982.

Koss, A. R., Sekimoto, K., Gilman, J. B., Selimovic, V., Coggon, M. M., Zarzana, K. J., Yuan, B., Lerner, B. M., Brown, S. S., Jimenez, J. L., Krechmer, J., Roberts, J. M., Warneke, C., Yokelson, R. J., and de Gouw, J.: Non-methane organic gas emissions from biomass burning: identification, quantification, and emission factors from PTR-ToF during the FIREX 2016 laboratory experiment, Atmos. Chem. Phys., 18, 3299-3319, https://doi.org/10.5194/acp-18-3299-2018, 2018.

Kuhlbusch, T. A., Lobert, J. M., Crutzen, P. J., and Warneck, P.: Molecular nitrogen emissions from denitrifcation during biomass burning, Nature, 351, 135-137, 1991.

Lee, B. H., Lopez-Hilfiker, F. D., Mohr, C., Kurten, T., Worsnop, D. R., and Thornton, J. A.: An iodide-adduct high-resolution time-of-flight chemical-ionization mass spectrometer: application to atmospheric inorganic and organic compounds, Environ. Sci. Technol., 48, 6309-6317, 2014.

Lee, D. C., Quigley, T. M., Norman, S., Christie, W., Fox, J., Rogers, K., and Hutchins, M.: National Cohesive Wildland Fire Management Strategy, US Department of the Interior, Washington, D.C., 2014. 
Lerner, B. M., Gilman, J. B., Aikin, K. C., Atlas, E. L., Goldan, P. D., Graus, M., Hendershot, R., Isaacman-VanWertz, G. A., Koss, A., Kuster, W. C., Lueb, R. A., McLaughlin, R. J., Peischl, J., Sueper, D., Ryerson, T. B., Tokarek, T. W., Warneke, C., Yuan, B., and de Gouw, J. A.: An improved, automated whole air sampler and gas chromatography mass spectrometry analysis system for volatile organic compounds in the atmosphere, Atmos. Meas. Tech., 10, 291-313, https://doi.org/10.5194/amt-10-2912017, 2017.

Li, Q., Jacob, D. J., Bey, I., Yantosca, R. M., Zhao, Y., Kondo, Y., and Notholt, J.: Atmospheric hydrogen cyanide (HCN): Biomass burning sources, ocean sink?, Geophys. Res. Lett., 27, 357-360, 2000.

Liu, X., Zhang, Y., Huey, L. G., Yokelson, R. J., Wang, Y., Jimenez, J. L., Campuzano-Jost, P., Beyersdorf, A. J., Blake, D. R., Choi, Y., St. Clair, J. M., Crounse, J. D., Day, D. A., Diskin, G. S., Fried, A., Hall, S. R., Hanisco, T. F., King, L. E., Meinardi, S., Mikoviny, T., Palm, B. B., Peischl, J., Perring, A. E., Pollack, I. B., Ryerson, T. B., Sachse, G. W., Schwarz, J. P., Simpson, I. J., Tanner, D. J., Thornhill, K. L., Ullman, K., Weber, R. J., Wennberg, P. O., Wisthaler, A., Wolfe, G. M., and Ziemba, L. D.: Agricultural fires in the southeastern US during SEAC ${ }^{4} \mathrm{RS}$ : Emissions of trace gases and particles and evolution of ozone, reactive nitrogen, and organic aerosol, J. Geophys. Res., 121, 7383-7414, 2016.

Liu, X., Huey, L. G., Yokelson, R. J., Selimovic,V., Simpson, I. J., Muller, M., Jimenez, J. L., Campuzano-Jost, P., Beyersdorf, A. J., Blake, D. R., Butterfield, Z., Choi, Y., Crounse, J. D., Day, D. A., Diskin, G. S., Dubey, M. K., Fortner, E., Hanisco, T. F., Hu, W., King, L. E., Kleinman, L., Meinardi, S., Mikoviny, T., Onasch, T. B., Palm, B. B., Peischl, J., Pollack, I. B., Ryerson, T. B., Sachse, G. W., Sedlacek, A. J., Shilling, J. E., Springston, S. R., St. Clair, J. M., Tanner, D. J., Teng, A. P., Wennberg, P. O., Wisthaler, A., and Wolfe, G. M.: Airborne measurements of western US wildfire emissions: Comparison with presscribed burning and air quality implications, J. Geophys. Res., 122, 6108-6129, 2017.

Liu, X., Luo, Z., Yu, C., Jin, B., and Tu, H.: Release mechanism of fuel-N into $\mathrm{NO}_{x}$ and $\mathrm{N}_{2} \mathrm{O}$ precursors during pyrolysis of rice straw, Energies, 11, 520, https://doi.org/10.3390/en11030520, 2018.

Lobert, J. M. and Warnatz, J.: Emissions from the combustion process in vegetation, in: Fire in the Environment: The Ecological, Atmospheric and Climatic Importance of Vegetation Fires, edited by: Crutzen, P. J. and Goldhammer, J. G., John Wiley and Sons, New York, NY, 1993.

Lobert, J. M., Scharffe, D. H., Hao, W. M., and Crutzen, P. J.: Importance of biomass burning in the atmospheric budgets of nitrogencontaining gases, Nature, 346, 552-554, 1990.

Lobert, J. M., Scharffe, D. H., Hao, W.-M., Kuhlbusch, T. A., Seuwen, R., Warneck, P., and Crutzen, P. J.: Experimental evaluation of biomass burning emissions: Nitrogen and carbon containing compounds, in: Global Biomass Burning: Atmospheric, Climatic, and Biospheric Implications, edited by: Levine, J. S., The MIT Press, Cambridge, MA, 1991.

Lucassen, A., Zhang, K., Warkentin, J., Mashammer, K., Glarborg, P., Marshall, P., and Kohse-Hoinghaus, K.: Fuel-nitrogen conversion in the combustion of small amines using dimethylamine and ethylamine as biomass-related model fuels, Combust. Flame, 159, 2254-2279, 2012.
Manfred, K. M., Washenfelder, R. A., Wagner, N. L., Adler, G., Erdesz, F., Womack, C. C., Lamb, K. D., Schwarz, J. P., Franchin, A., Selimovic, V., Yokelson, R. J., and Murphy, D. M.: Investigating biomass burning aerosol morphology using a laser imaging nephelometer, Atmos. Chem. Phys., 18, 1879-1894, https://doi.org/10.5194/acp-18-1879-2018, 2018.

Manion, J. A., Huie, R. E., Levin, R. D., Burgess Jr., D. R., Orkin, V. L., Tsang, W., McGivern, W. S., Hudgens, J. W., Knyazev, V. D., Atkinson, D. B., Cahi, E., Tereza, A. M., Lin, C.-Y., Allison, T. C., Mallard, W. G., Westley, F., Herron, J. T., Hampson, R. F., and Frizzell, D. H.: NIST Chemical Kinetics Database, NIST Standard Reference Database 17, Version 7.0 (Web Version), Release 1.6.8, available at: http://kinetics.nist.gov/ (last access: 1 June 2020), 2015.

Marx, O., Brümmer, C., Ammann, C., Wolff, V., and Freibauer, A.: TRANC - a novel fast-response converter to measure total reactive atmospheric nitrogen, Atmos. Meas. Tech., 5, 1045-1057, https://doi.org/10.5194/amt-5-1045-2012, 2012.

May, A. A., McMeeking, G. R., Lee, T., Taylor, J. W., Craven, J. S., Burling, I. R., Sullivan, A. P., Akagi, S. K., Collett Jr., J. L. J., Flynn, M., Coe, H., Urbanski, S. P., Seinfeld, J. H., Yokelson, R. J., and Kreidenweis, S. M.: Aerosol emissions from prescribed fires in the United States: A synthesis of laboratory and aircraft measurements, J. Geophys. Res., 119, 11826-11849, 2014.

McMeeking, G. R., Kreidenweis, S. M., Baker, S., Carrico, C. M., Chow, J. C., Collett Jr., J. L., Hao, W. M., Holden, A. S., Kirchstetter, T. W., Malm, W. C., Moosmuller, H., Sullivan, A. P., and Wold, C. E.: Emissions of trace gases and aerosols during the open combustion of biomass in the laboratory, J. Geophys. Res., 114, D19210, https://doi.org/10.1029/2009JD011836, 2009.

Min, K.-E., Washenfelder, R. A., Dubé, W. P., Langford, A. O., Edwards, P. M., Zarzana, K. J., Stutz, J., Lu, K., Rohrer, F., Zhang, Y., and Brown, S. S.: A broadband cavity enhanced absorption spectrometer for aircraft measurements of glyoxal, methylglyoxal, nitrous acid, nitrogen dioxide, and water vapor, Atmos. Meas. Tech., 9, 423-440, https://doi.org/10.5194/amt-9423-2016, 2016.

NOAA: Fire Lab 2016, available at: https://www.esrl.noaa.gov/csl/ projects/firex/firelab/, last access: 20 July 2020a.

NOAA: FIREX Fire Lab 2016 data, available at: https: //esrl.noaa.gov/csd/groups/csd7/measurements/2016firex/ FireLab/DataDownload/, last access: 21 July 2020b.

Paatero, P. and Tapper, U.: Positive matrix factorization: A nonnegative factor model with optimal utilization of error estimates of data values, Environmetrics, 5, 111-126, 1994.

Prenni, A. J., Levin, E. J. T., Benedict, K. B., Sullivan, A. P., Schurman, M. I., Gebhart, K. A., Day, D. E., Carrico, C. M., Malm, W. C., Schichtel, B. A., Collett Jr., J. L., and Kreidenweis, S. M.: Gas-phase reactive nitrogen near Grand Teton National Park: Impacts of transport, anthropogenic emissions, and biomass burning, Atmos. Environ., 89, 749-756, 2014.

Ren, Q. Q., Zhao, C. S., Wu, X. X., Liang, C., Chen, X. P., Shen, J. Z., and Wang, Z.: Formation of $\mathrm{NO}_{x}$ precursors during wheat straw pyrolysis and gasification with $\mathrm{O}_{2}$ and $\mathrm{CO}_{2}$, Fuel, 89, 1064-1069, 2010.

Roberts, J. M., Langford, A. O., Goldan, P. D., and Fehsenfeld, F. C.: Ammonia measurements at Niwot Ridge, Colorado, and Point Arena, California, using the tungsten oxide denuder tube technique, J. Atmos. Chem., 7, 137-152, 1988. 
Roberts, J. M., Veres, P. R., Cochran, A. K., Warneke, C., Burling, I. R., Yokelson, R. J., Lerner, B. M., Gilman, J. B., Kuster, W. C., Fall, R., and de Gouw, J.: Isocyanic acid in the atmosphere and its possible link to smoke-related health effects, P. Natl. Acad. Sci. USA, 108, 8966-8971, 2011.

Saylor, R. D., Edgerton, E. S., Hartsell, B. E., Baumann, K., and Hansen, D. A.: Continuous gaseous and total ammonia measurements from the southeastern aerosol research and characterization (SEARCH) study, Atmos. Environ., 44, 4994-5004, 2010.

Schwab, J. J., Li, Y., Bae, M.-S., Demerjian, K. L., Hou, J., Zhou, X., Jensen, B., and Pryor, S.: A laboratory intercomparision of real-time gaseous ammonia measurement methods, Environ. Sci. Technol., 41, 8412-8419, 2007.

Sekimoto, K., Li, S.-M., Yuan, B., Koss, A. R., Coggon, M. M., Warneke, C., and de Gouw, J.: Calculation of the sensitivity of proton-transfer-reaction mass spectrometry (PTR-MS) for organic trace gases using molecular properties, Int. J. Mass Spectrom., 421, 71-94, 2017.

Sekimoto, K., Koss, A. R., Gilman, J. B., Selimovic, V., Coggon, M. M., Zarzana, K. J., Yuan, B., Lerner, B. M., Brown, S. S., Warneke, C., Yokelson, R. J., Roberts, J. M., and de Gouw, J.: High- and low-temperature pyrolysis profiles describe volatile organic compound emissions from western US wildfire fuels, Atmos. Chem. Phys., 18, 9263-9281, https://doi.org/10.5194/acp18-9263-2018, 2018.

Selimovic, V., Yokelson, R. J., Warneke, C., Roberts, J. M., de Gouw, J., Reardon, J., and Griffith, D. W. T.: Aerosol optical properties and trace gas emissions by PAX and OP-FTIR for laboratory-simulated western US wildfires during FIREX, Atmos. Chem. Phys., 18, 2929-2948, https://doi.org/10.5194/acp18-2929-2018, 2018.

Shaddix, C. R., Harrington, J. E., and Smyth, K. C.: Quantitative measurements of enhanced soot production in a flickering methane/air diffusion flame, Combust. Flame, 99, 723-732, 1994.

Stockwell, C. E., Yokelson, R. J., Kreidenweis, S. M., Robinson, A. L., DeMott, P. J., Sullivan, R. C., Reardon, J., Ryan, K. C., Griffith, D. W. T., and Stevens, L.: Trace gas emissions from combustion of peat, crop residue, domestic biofuels, grasses, and other fuels: configuration and Fourier transform infrared (FTIR) component of the fourth Fire Lab at Missoula Experiment (FLAME-4), Atmos. Chem. Phys., 14, 9727-9754, https://doi.org/10.5194/acp-14-9727-2014, 2014.

Stockwell, C. E., Veres, P. R., Williams, J., and Yokelson, R. J.: Characterization of biomass burning emissions from cooking fires, peat, crop residue, and other fuels with high-resolution proton-transfer-reaction time-of-flight mass spectrometry, Atmos. Chem. Phys., 15, 845-865, https://doi.org/10.5194/acp-15845-2015, 2015.

Stockwell, C. E., Christian, T. J., Goetz, J. D., Jayarathne, T., Bhave, P. V., Praveen, P. S., Adhikari, S., Maharjan, R., DeCarlo, P. F., Stone, E. A., Saikawa, E., Blake, D. R., Simpson, I. J., Yokelson, R. J., and Panday, A. K.: Nepal Ambient Monitoring and Source Testing Experiment (NAMaSTE): emissions of trace gases and light-absorbing carbon from wood and dung cooking fires, garbage and crop residue burning, brick kilns, and other sources, Atmos. Chem. Phys., 16, 11043-11081, https://doi.org/10.5194/acp-16-11043-2016, 2016 a.
Stockwell, C. E., Jayarathne, T., Cochrane, M. A., Ryan, K. C., Putra, E. I., Saharjo, B. H., Nurhayati, A. D., Albar, I., Blake, D. R., Simpson, I. J., Stone, E. A., and Yokelson, R. J.: Field measurements of trace gases and aerosols emitted by peat fires in Central Kalimantan, Indonesia, during the 2015 El Niño, Atmos. Chem. Phys., 16, 11711-11732, https://doi.org/10.5194/acp-16-117112016, 2016 b.

Stockwell, C. E., Kupc, A., Witkowski, B., Talukdar, R. K., Liu, Y., Selimovic, V., Zarzana, K. J., Sekimoto, K., Warneke, C., Washenfelder, R. A., Yokelson, R. J., Middlebrook, A. M., and Roberts, J. M.: Characterization of a catalyst-based conversion technique to measure total particulate nitrogen and organic carbon and comparison to a particle mass measurement instrument, Atmos. Meas. Tech., 11, 2749-2768, https://doi.org/10.5194/amt-11-2749-2018, 2018.

Taylor, S. W., Wotton, B. M., Alexander, M. E., and Dalrymple, G. N.: Variation in wind and crown fire behaviour in a northern jack pine-black spruceforest, Can. J. Forest Res., 34, 1561-1576, 2004.

Ulbrich, I. M., Canagaratna, M. R., Zhang, Q., Worsnop, D. R., and Jimenez, J. L.: Interpretation of organic components from Positive Matrix Factorization of aerosol mass spectrometric data, Atmos. Chem. Phys., 9, 2891-2918, https://doi.org/10.5194/acp-92891-2009, 2009.

Veres, P. R., Roberts, J. M., Burling, I. R., Warneke, C., de Gouw, J., and Yokelson, R. J.: Measurements of gasphase inorganic and organic acids from biomass fires by negative-ion proton-transfer chemical-ionization mass spectrometry (NI-PT-CIMS), J. Geophys. Res.-Atmos., 115, D23302, https://doi.org/10.1029/2010JD014033, 2010.

Warneke, C., Roberts, J. M., Veres, P., Gilman, J. B., Kuster, W. C., Burling, I. R., Yokelson, R. J., and de Gouw, J. A.: VOC identification and inter-comparison from laboratory biomass burning using PTR-MS and PIT-MS, Int. J. Mass Spectrom., 303, 6-14, 2011.

Westerling, A. L., Hidalgo, H. G., Cayan, D. R., and Swetnam, T. W.: Warming and earlier spring increase western us forest wildfire activity, Science, 313, 940-943, 2006.

Williams, E. J., Baumann, K., Roberts, J. M., Bertman, S. B., Norton, R. B., Fehsenfeld, F. C., Springston, S. R., Nunnermacker, L. J., Newman, L., Olszyna, K., Meagher, J., Hartsell, B., Edgerton, E., Pearson, J. R., and Rodgers, M. O.: Intercomparison of ground-based $\mathrm{NO}_{y}$ measurement techniques, J. Geophys. Res.Atmos., 103, 22261-22280, https://doi.org/10.1029/98JD00074, 1998.

Wotton, B. M., Gould, J. S., McCaw, W. L., Cheney, N. P., and Taylor, S. W.: Flame temperature and residence time of fires in dry eucalypt forest, Int. J. Wildland Fire, 21, 270-281, 2012.

Yokelson, R. J., Griffith, D. W. T., and Ward, D. E.: Openpath Fourier transform infrared studies of large-scale laboratory biomass fires, J. Geophys. Res.-Atmos., 101, 21067-21080, 1996.

Yokelson, R. J., Crounse, J. D., DeCarlo, P. F., Karl, T., Urbanski, S., Atlas, E., Campos, T., Shinozuka, Y., Kapustin, V., Clarke, A D., Weinheimer, A., Knapp, D. J., Montzka, D. D., Holloway, J., Weibring, P., Flocke, F., Zheng, W., Toohey, D., Wennberg, P. O., Wiedinmyer, C., Mauldin, L., Fried, A., Richter, D., Walega, J., Jimenez, J. L., Adachi, K., Buseck, P. R., Hall, S. R., and Shetter, R.: Emissions from biomass burning in the Yucatan, Atmos. 
Chem. Phys., 9, 5785-5812, https://doi.org/10.5194/acp-9-57852009, 2009.

Yokelson, R. J., Andreae, M. O., and Akagi, S. K.: Pitfalls with the use of enhancement ratios or normalized excess mixing ratios measured in plumes to characterize pollution sources and aging, Atmos. Meas. Tech., 6, 2155-2158, https://doi.org/10.5194/amt6-2155-2013, 2013a.

Yokelson, R. J., Burling, I. R., Gilman, J. B., Warneke, C., Stockwell, C. E., de Gouw, J., Akagi, S. K., Urbanski, S. P., Veres, P., Roberts, J. M., Kuster, W. C., Reardon, J., Griffith, D. W. T., Johnson, T. J., Hosseini, S., Miller, J. W., Cocker III, D. R., Jung, H., and Weise, D. R.: Coupling field and laboratory measurements to estimate the emission factors of identified and unidentified trace gases for prescribed fires, Atmos. Chem. Phys., 13, 89-116, https://doi.org/10.5194/acp-13-89-2013, 2013b.
Zarzana, K. J., Selimovic, V., Koss, A. R., Sekimoto, K., Coggon, M. M., Yuan, B., Dubé, W. P., Yokelson, R. J., Warneke, C., de Gouw, J. A., Roberts, J. M., and Brown, S. S.: Primary emissions of glyoxal and methylglyoxal from laboratory measurements of open biomass burning, Atmos. Chem. Phys., 18, 15451-15470, https://doi.org/10.5194/acp-18-15451-2018, 2018. 